\title{
MARKET DELINEATION AND THE JUSTICE DEPARTMENT'S MERGER GUIDELINES*
}

\author{
GREGORY J. WERDEN**
}

\begin{abstract}
On June 14, 1982, the U.S. Department of Justice released new Merger Guidelines which outline its approach to enforcing section 7 of the Clayton Act. Perhaps the most innovative and important aspect of the Guidelines is their approach to market delineation. Gregory Werden, who was intimately involved in the preparation of the Guidelines, explores the practical applications of the Guidelines' market delineation principles. He finds that the Guidelines provide no rules for delineating markets but nevertheless make a major contribution by providing a coherent conceptual framework for thinking about the issues.
\end{abstract}

On June 14, 1982, the U.S. Department of Justice released new Merger Guidelines. 1 The Guidelines outline the Department's methods for determining the likely competitive effects of mergers and acquisitions under section 7 of the Clayton $\mathrm{Act}^{2}$ and detail specific enforcement standards for various types of mergers. Perhaps the most interesting and innovative aspect of the Guidelines is their approach to market delineation, a feature of particular significance because market delineation is the most important step in inerger analysis. ${ }^{3}$ This article explores the logical underpinnings, theoretical details, and practical application of the Guidelines' market delineation principles.

\section{The General Principles of Market Delineation Embodied IN THE GUIDELINES}

A. The Concept of an Antitrust Market.

Section 7 of the Clayton Act prohibits mergers the effect of which "may be substantially to lessen competition or to tend to create a mo-

* The views expressed in this article do not necessarily represent those of the U.S. Department of Justice.

** Senior Economist, Antitrust Division, U.S. Department of Justice. B.A., University of Cincinnati, 1973; M.A., University of Cincinnati, 1974; M.A., University of Wisconsin, 1976; Ph.D., University of Wisconsin, 1977.

1. The Guidelines are reprinted at 2 TRADE REG. REP. (CCH) II 4501-4505.

2. Ch. 323, \& 7, 38 Stat. 730 (1914) (current version at 15 U.S.C. \& 18 (Supp. IV 1980)).

3. See, eg., 3 J. von Kalinowski, ANTtrRust Laws and Trade Regulation $\$ 18.01$ [2]. 
nopoly." Therefore, application of the Act requires predictions about the effects on competition of changes im market structure. Economics contributes much to this undertaking, and the concept of a "market" is central to economic theory. Thus, principles of market delineation for merger analysis could perhaps be borrowed directly from economics. Nevertheless, economists liave contributed little to market delineation in the antitrust context. ${ }^{5}$ Most prominently, they liave provided market delineation tests rooted in the writings of nineteenth century economic theorists about inarkets, ${ }^{6}$ but those early economists' vague notions about markets were not directed toward the analysis of mergers under the Clayton Act.7 Furthermore, the concept of market delineation as it

4. 15 U.S.C. $\$ 18$ (Supp. IV 1980).

5. Economists have readily acknowledged that their profession has contributed little in this area. In a major address to the American Economic Association's 1981 convention, George Stigler remarked: "My lament is that this battle on market definitions . . . has received virtually no attention from us economists. Except for a casual flirtation with cross elasticities of demand and supply, the determination of markets has remained an undeveloped area of economic research at either the theoretical or empirical level." The Economists and the Problem of Monopoly, 72 AM. ECON. REV. (PAP. \& PROC.) 1, 9 (1982). Another economist has made a similar point:

Because economists, from Adam Smith forward, have with confidence and enthusiasm ... written about markets, it is plausible to expect that they would have had quite a bit to contribute to the resolution of the market-definition issue. Plausible but erroneous.

Curiously enough, economists have had comparatively little to say about low to delineate markets.

Horowitz, Market Defunition in Antitrust Analysis: A Regression-Based Approach, 48 S. Econ. J., 1, 1-2 (1981).

6. Economic theory long ago dennonstrated that within an "economic market" all units of a good must trade at the same price if the good is completely homogeneous and there is no price discrimination. In less ideal economic markets, different products will trade at different prices, but the relationship among prices will be fixed. Thus, changes in the price of one product should be highly correlated with changes in the price of other products in the same economic inarket. A concrete proposal for translating this prediction of economic theory into a practical market delineation test was made recently by Ira Horowitz. See Horowitz, supra note 5, at 6-11. Horowitz cites numerous authorities for the theoretical basis of his test, particularly the work of William Stanley Jevons (1835-1882). Id. at 6-7. To its credit, the Horowitz test is not mechanical, and Horowitz does not claim that it is either necessary or sufficient for a product and area to "pass" the test in order to qualify as a market.

In addition to significant limitations that Horowitz himself notes, id. at 7-9, Kenneth Elzinga and Thomes Hogarty have concluded that for "conceptual" and "practical" reasons "price data are of little use in . . . market delineation." Elringa \& Hogarty, The Problem of Geographic Market Delineation in Antimerger Suits, 18 ANTITRUST BULL. 45, 48 (1973). Relying on the work of Alfred Marshall (1842-1924), see id. at 47-48, 50, Elzinga and Hogarty conclude that: "A market encompasses the.primary demand and supply forces that determine a product's price and the geographic market area is the area that encompasses these buyers and sellers." Id. at 47. This "definition" seems of little practical relevance to merger analysis, yet Elzinga and Hogarty wring from it a mechanical test for geographic market delineation that uses only shipments data. This test has gaimed considerable acceptance despite serious shortcomings. See infra notes 157-65 and accompanying text.

7. Although Congress enacted the Sherman Act, 26 Stat. 209, in 1890 and the Clayton Act, 38 Stat. 730, im 1914, only recently has market delineation been used in antitrust analysis. The earliest market delineation case still considered notable is United States v. Columbia Steel Co., 
is used in the antitrust context is quite foreign to economic theorists, and it is only this context that gives ineaning to the inarket delineation question.

In economic theory, the term market is a useful but ill-defined abstraction. Economic theory does not require the delineation of markets, and most economists would not know how to begin to delineate one. But even if economists routinely delineated markets, the markets constructed in some phases of economic analysis would not be suitable for merger analysis under the Clayton Act. Markets are an analytical tool, and in economics and law as well as in carpentry and auto mechanics the most useful tools are those designed for a specific job. An important premise of the Guidelines is that market delineation must not be based on the abstract notions of economics or any other discipline. The Guidelines employ the concept of an "antitrust market," a market delineated for the sole purpose of antitrust analysis. Even within the relatively narrow context of antitrust analysis, however, there is not a single, correct approach to market delineation; how markets should be delineated depends on the exact manner in which the delineated market will be used. The Guidelines tailor market delineation to the specific analytical paradigm used to analyze mergers under the Clayton Act and can only be fully understood in this context.

\section{B. The Basic Analytic Paradigm of the Guidelines.}

The Guidelines' basic analytic paradigm for horizontal mergers logically evolves from their "unifying theme" - "that inergers should not be permitted to create or enhance 'market power' or to facilitate its exercise." 8 Market power is the ability of a single seller or group of sellers acting collectively profitably to increase and maintain prices


Columbia Steel was decided under the original section 7, prior to its amendment by the CellerKefauver Act, 64 Stat. 1125, in 1950. The 1950 amendments explicitly introduced the market delineation question. The original section 7 prohibited mergers that substantially lessened competition between the merging firms, see 38 Stat. 731; the amended section 7 prohibits mergers that lessen competition "in any line of commerce in any section of the country." 64 Stat. 1125. The phrase "in any line of commerce in any section of the country" has been interpreted to mean "in any relevant market." See, e.g., J. voN KaLINOwsku, supra note 3, at § 18.01[1]. The earliest important case decided under the amended section 7 is Brown Shoe Co. v. United States, 370 U.S. 294 (1962), which is still considered the leading case.

8. 2 TRADE REG. REP. (CCH) If 4501. In this regard, the Guidelines "reflect the congressional intent that merger enforcement should interdiet competitive problems in their imcipiency." Id. This congressional intent was clearly expressed in the Senate committee report on the 1950 amendments to section 7: "The intent lere . . . is to cope with monopolistic tendencies in their incipiency and well before they have attained such effects as would justify a Sherman Act proceeding." S. REP. No. 1775, 81 st Cong., 2d Sess. 45, reprinted in 1950 U.S. CODE CONG. \& AD. NEWs 4296. The Supreme Court has also explicitly noted this congressional purpose: "Section 7 
above competitive levels. ${ }^{9}$ Although the Guidelines address the problem of individual dominant sellers, ${ }^{10}$ such sellers are relatively uncommon, and the Guidelines concentrate on collective exercises of market power. As a result, the Guidelines primarily attempt to assess a merger's probable effect on the likelihood of tacit or explicit collusion. ${ }^{11}$

The Guidelines recognize that the size distribution of sellers in a market is the primary, but not the exclusive, indicator of the likelihood of collusion. Neither tacit nor explicit collusion is likely to occur unless a relatively small number of sellers accounts for a relatively large portion of the market. ${ }^{12}$ To measure market concentration, the Guidelines use the Herfindahl-Hirschman Index (HHI) rather than the traditional four-firm concentration ratio, ${ }^{13}$ but any sensible measure of concentration must be based on the same basic information-the shares of the firms in some market. Although it can be argued that market sliare statistics should not be the cornerstone of section 7 analysis, there seems to be no practical alternative for predicting the likelihood of collusion. ${ }^{14}$

of the Clayton Act was intended to arrest the anticompetitive effects of market power in their incipiency." FTC v. Procter \& Gamble Co., 386 U.S. 568,577 (1967).

Although the Guidelines' ultimate goal is to prevent exercises of market power similar to those proscribed by sections 1 and 2 of the Sherman Act, 15 U.S.C. $\$ \$ 1-2$ (1976), the Guidelines do not insist that such conduct occur or even be highly likely. The Guidelines' repeated references to collusion seen to have misled some commentators.in this regard. See Axinn \& Stoll, Government Approves Merging Section 7 into Sherman Act, N.Y.L.J., June 24, 1982, at 1.

9. See, eg., Guidelines, 2 TRADE REg. REP. (CCH) I 4501. Market power need not be exercised by raising price, but such exercises generally take that form in the absence of price regulation. Moreover, if raising price would not be profitable, it is extremely unlikely that some other exercise of market power would be.

10. See id. \4503.102.

11. See generally Guidelines, 2 TRADE REg. REP. (CCH) 19 4501-4503.

12. Id 14503.10. Empirical research tends to confirm this. See Hay \& Kelley, An Empirical Survey of Price-Fixing Conspiracies, 17 J.L. \& EcoN. 13 (1974); see also Fraas \& Greer, Marker Sinucture and Price Collusion: An Empirical Analysis, 24 J. InDus. ECoN. 21 (1977).

13. 2 TRADE REG. REP. (CCH) II 4503.10, 4503:101. The HHI is the sum of the squares of the shares of all the firms in the market. The four-firm concentration ratio is the percentage of the market accounted for by the four largest firms. There are many other such summary measures of the size distribution of sellers. See generally F. Scherer, INDUSTRIAL MARKET STRUCTURE AND Economic Performance 56-59 (2d ed. 1980).

The effect of the merger on market concentration is, of course, also measured through market shares. Using the HHI, the effect of the merger on concentration is twice the product of the shares of the merging firms. See, eg., Guidelines, 2 TRADE REG. REP. (CCH) I 4503.101 n.30.

14. In any event, it is doubtful that the courts would accept an unfamiliar approach.

Landes and Posner have argued that market definition is necessary only because the direct determinents of market power (ie.e, elasticities of demand and supply) cannot be measured easily. See Landes \& Posnet, Market Power in Antitrust Cases, 94 HARv. L. Rev. 937, 962 (1981); see also R. Posner, ANtitrust LAw: AN Economic Perspective 125 (1976). This is true, however, only when the issue is "whether a firm has market power," which is the ouly question that Landes and 
Thus, in fashioning a rational approach to analyzing horizontal mergers, the problem is not whether to focus on market shares, but how to make market shares consistent and reliable indicators of the likehhood of collusion. This requires that a variety of factors affecting the relationship between market concentration and the likelihood of collusion be brought explicitly into the analysis. Given any size distribution of firms, these factors affect the ease with which collusive agreements can be reached or maintained and the profitability of any collusive agreement. The Guidelines' list of relevant factors includes the degree of product heterogeneity, the quahity and availability of substitutes not mcluded in the inarket, the availability to firms of information about competitors' transactions, buyers' characteristics and purchasing habits, and any history of anticompetitive conduct or performance. ${ }^{15} \mathrm{Al}-$ though these factors merit consideration, tley tend to be unquantifiable and to lack precise relationships with the likelihood of collusion. Therefore, the Guidelines use these factors primarily as pluses or minuses in relatively close cases. ${ }^{16}$

Two other factors influence unore substantially the likelihood of collusion, and the Guidelines recognize their greater significance. The likelihood of a collusive price increase by the present sellers of a product depends im part on the degree of competition they face frown firms not currently selling the product. Such competition can assume either or both of two forms: (1) firms that currently produce other products may switch to the production of the product in question if they can produce it witl existing facilities; and (2) firms may construct new facilities to produce the product. The former is "supply substitution" and

Posner discuss. See 94 Harv. L. Rev. at 962 (emphasis added). Most section 7 cases, though, turn not on whether the merger enhances or creates inarket power in a single firm, but on whether the merger would significantly increase the likelihood of a collusive exercise of narket power by several firms. In such cases, there is no substitute for market delineation because market shares are essential to the analysis.

It has been argued, however, that if the products in a market are highly differentiated, market shares will not be useful indicators and market delineation is neither necessary nor particularly useful. See Markovits, Predicting the Competitive Impact of Horizontal Mergers in a Monopolistically Competitive World: A Non-Market-Oriented Proposal and Critique of the Market Definition. Market Share-Market Concentration Approach, 56 TEX. L. REV. 587 (1978); see also Schmalensee, Another Look at Market Povier, 95 HARv. L. Rev. 1789, 1799-800 (1982). A less drastic solution to this problem is to adjust market shares in some way to take into account the differences between products. See Kaplow, The Accuracy of Traditional Market Power Analysis and a Direct Adjustment Alternative, 95 HARv. L. REv. 1817 (1982). The Guidelines take still another approach. They delineate markets and measure shares without expleit adjustments, and, in interpreting the shares, they consider how directly the merging firms' products compete. See 2 TRADE REG. REP. (CCH) I 4503.301(c).

15. 2 TRADE REG. Rep. (CCH) II 4503.301-.304.

16. Id. II $4503.10,4503.30$. 
the latter is "de novo entry." Although these considerations are far too important to be mere tie breakers, there is no single correct way to incorporate thein into the analysis.

There are three ways to account for supply substitutability. Under a market delineation approach, the market for the product in question could be defined to include all good substitutes in production. For example, the relevant market for the merger of two hubcap inakers could be defined as all hight inetal stampings, which would include all products produced with the facilities used to inake hubcaps, even if consumption substitution were impossible. By contrast, under the share ineasurement approach, the inarket for the product in question could be defined to imclude only products that are good substitutes in consumption. Firms capable of producing and selling the relevant product(s), however, would be assigned shares in that inarket based on their capacity to sell, even if they were not currently selling the product. Thus, all firms in the light metal stamping industry, even those not producing hubcaps, could be assigned shares in a inarket for hubcaps. The third alternative would be to ignore supply substitution in both market delineation and share measurement but to take it into account in interpreting the significance of the shares. Under this approach, the merger of two hubcap producers with high apparent market shares in a highly concentrated inarket could nevertheless be permitted because collusion among hubcap producers would induce producers of other hight metal stampings to switch to hubcaps. In the case of de novo entry, only the second and third alternatives are available. Market shares can be either explicitly reduced or implicitly discounted to reflect the effect of entry.

The Guidelines elect the share measurement approach for supply substitutability ${ }^{17}$ and the share significance approach for de novo entry. ${ }^{18}$ In each case the rationale is to make the inarket share figures as meaningful as possible. In the case of de novo entry, the Guidelines' rationale is very simple. Because it is not possible to measure or even reasonably to predict the amount of entry that a particular price increase would induce over a particular period of time, any exphcit adjustment of shares would be totally arbitrary. To avoid inaking such arbitrary adjustments, the Guidelines consider de novo entry im interpreting shares. The Guidelines nevertheless fully recognize the importance of de novo entry and clearly state that the Department is unlikely to challenge a merger in a market if "entry into [it] is so easy that ex-

17. See id. If 4502, 4502.201 .

18. See id. If $4502,4503.20$. 
isting competitors could not succeed in raising price for any significant period of time." 19

In the case of supply substitutability, it is possible, at least in principle, to quantify the amount of supply substitution that a particular price increase would induce. ${ }^{20}$ Therefore, to make market shares as meaningful as possible, the effects of supply substitutability should be incorporated explicitly in either market delineation or share measurement. If supply substitutability were always perfect where it existed at all, the result would be exactly the saine using either approach. Although the Guidelines elect to incorporate the effects of supply substitutability in measuring shares rather than in delineating markets, they indicate that if substitutability in production is "nearly universal," products may be lumped together "as a matter of convemence" even though each will be considered to constitute a distinct market. ${ }^{21}$

The Guidelines adopt the share measurement approach because supply substitutability often is subject to constramts that are easily incorporated only in measuring shares.22 For example, consider the inerger of two airlines that fly between Chicago and New York. Although air travel between Chicago and New York probably has no

19. Id. \ 4503.20 .

20. The Guidelines consider as "production substitution" only that substilution which could "easily and economically" occur using "existing productive and distributive facilities . . . within six months in response to a small but significant and non-transitory increase in price." Id. If 4502.201. Thus, substitution that could occur only after costly or time-consuming modification of existing facilities is considered de novo entry. See id. I 4503.20. By restricting the definition of supply substitution in this way, the Guidelines make it possible to incorporate explicitly the effects of supply substitutability in market.shares. The task, lowever, is difficult; one must determine both how-much a firm could produce and how much it could sell. In a market for a homogeneous, undifferentiated good, the ability to produce generally will be exactly the same as the ability to seil, and this simplifies the measuremeut problem. However, in a market for a highly differentiated product, a firm may be quite capable of producing the good, but totally unable to sell it in significant quantities, at least within six months in reaction to a five percent price increase. Such a firm should be assigned a share far below that indicated by its ability to produce, perhaps even a share of zero.

21. Id. I 4502.201 n.16.

22. Even if supply substitutability is perfect, incorporating it into market delineation presents serious conceptual problems. Products that are good substitutes in production often will not be good substitutes in consumption. For example, various light metal stampings may be perfect substitutes in production but not substitutes in consumption at all. It would be awkward to think in terms of exercising market power in a "market" for various noncompeting "light metal stampings." It would be more than awkward if some light metal stampings had good substitutes in cousumption in the form of "molded plastic products." In that event it would be impossible to increase the price for all hight metal stampings and therefore meaningless to speak of market power in such a "market." Adding molded plastics to the "market" would only compound the problem, however, if the merger at hand involved producers of hubcaps, for which molded plastics are not good substitutes in consumption. Thus, the Guidelines' approach has considerable appeal even if supply substitutability is perfect. 
good substitute from the point of view of travelers, there may be good substitutes from the poimt of view of suppliers. If every airplane owned by a Umited States air carrier could be quickly and economically diverted to the Chicago-New York route, one could define the relevant inarket as air service in the United States, ${ }^{23}$ or one could define the market as air service between Chicago and New York but assign shares in that market according to the total number of airplanes (or seats) each United States carrier owns. In this case both approaches produce the same result. Alternatively, the number of airplanes from other routes that could be diverted to the Chicago-New York route might be constrained by the availability of landing slots and gate space at the relevant airports. The only meaningful way to incorporate supply substitutability in this case would be to estimate the extent to which each carrier could divert airplames and to use those estimates in coinputing shares.

One final consideration in making narket sliares as meaningful as possible is the clioice of a measurement base (i.e., sales, production, or capacity) and, in particular, a measurement point (i.e., the point of production or the point of consumption). The Guidelines imclude little about the choice of a measurement base. They only indicate that "the Department will use the measurement base that is the best indicator of the likely effect of the merger on market power" if the "availability of data" makes "a choice . . possible." 24 This is a reasonable position because the best share measure should be determined on a case-by-case basis. The Guidelines specify more clearly the point of measurement; in general, they focus on sellers rather than buyers ${ }^{25}$ and nneasure shares according to where a product is produced rather than where it is consumed. ${ }^{26}$ The amount of production or productive capacity of firms in the relevant area determines market shares rather than the amount of consumption of their products in the area. ${ }^{27}$

23. Arguments that only airplanes on geographically proximate routes or routes that share a common origin or destination can be easily substituted have led to the use of regional, rather than national, markets. See, e.g., Carlton, Landes \& Posner, Benefits and Costs of Airline Mergers: $A$ Case Study, 11 BELL J. ECON. 65, 75-77 (1980).

24. 2 TRAde Reg. Rep. (CCH) 4502.40 n.26.

25. See id $4502.30 \& \mathrm{n} .21$.

26. See id. II 4502.30 n.21, 4502.40 .

27. The antitrust literature and case law have almost completely ignored the point of measurement. Courts and commentators seem to prefer to measure shares at the point of consumption, but they have not explained why. The most likely explanation is the assumption that antitrust analysis must focus on the consumers who would be the victims of anticompetitve conduct. See, e.g., R. PosNer, supra note 14, at 127. Neither the Clayton Act nor judicial imterpretations of the Act require this focus, however, and the Guidelines do not adopt it. 
The Guidelines' preference for the point of production over the point of consumption derives from the theory that a firm's production or capacity to produce indicates its competitive impact regardless of where its production is consumed. This is clearly the case if the product in question is homogeneous and undifferentiated because consuiners will readily substitute one firm's product for that of another. Production of a homogeneous and undifferentiated good can easily be diverted from one point of consumption to another, and the capacity to produce is easily converted into sales. But if the product is highly differentiated, consumers will not so readily substitute one firm's product for that of another. In that case, a firm that can sell only half the amount it can produce and that is shipping half of its output out of a particular area might not be able to mcrease significantly its total sales in the area if the price rose, either by diverting production sold in another area or by increasing production. Therefore, if the product is highly differentiated, market shares should be measured at the point of consumption rather than at the poimt of production. The Guidelines do not note this exception, but they do note a similar exception that also should be made in the case of price discrimination: ${ }^{28}$ if price discrimination is possible, the Guidelines sanction the measurement of shares based on consumption by those against whoin the discrimination could occur.

The foregoing considerations have a profound effect on market delineation, the remaining step in the Guidelines' paradigm. ${ }^{29}$ Market delineation is part of an analysis designed to determine whether a merger will create or enhance market power. Mergers affect inarket power primarily by increasing the likelihood that a few competitors will coordinate their activities and act monopolistically. Such collusion is undesirable because monopolists tend to restrict output and charge prices that exceed competitive levels. If, however, the sole present and future seller of a product in an area cannot profitably increase price significantly, that "monopolist" is not of antitrust concern. It follows that the merger of any two sellers of that product in that area also would be of no concern. Thus, before a product and area can be considered a inarket for the purposes of section 7 analysis, it must be determined that market power could be exercised over that product in that area. The Guidelines base their approacl to market delineation directly on this premise, asking whetler a significant increase in the price

28. See 2 Trade Reg. Rep. (CCH) I 4502.30 .

29. See infra text accompanying notes 31-35. 
of a product in an area would be profitable for a hypothetical monopolist of that product in that area. ${ }^{30}$

In summary, the Guidelines' paradigm for the analysis of horizontal mergers consists of six steps. First, markets consisting of groups of products and areas are delineated for each product and plant of each of the merging firms. Second, present competitors in each of the markets are identified by determining who sells or could quickly and economically sell in the markets using existing facilities. ${ }^{31}$ Third, market shares are assigned according to the sales or the capacity to sell of each of the present competitors in the market, which may imclude firms not currently selling. ${ }^{32}$ Fourth, the size distribution of firms is examined in light of various other factors to assess the likelihood of collusion in the markets. ${ }^{33}$ Fifth, the shares of the merging firms are scrutinized to determine whether the merger significantly increases the likelihood of collusion. ${ }^{34}$ Sixth, entry conditions are examined to determine whether collusion by present competitors would be profitable. ${ }^{35}$

In its simplest form, this paradigm poses four questions, each of which must be answered affirmatively before a horizontal merger will be challenged by the Department: (1) if there were only one present and future seller of a product in an area, would it be able profitably to increase its price; (2) is it likely that present competitors would be able to coordinate their activities and act monopolistically; (3) would the merger significantly increase the likelihood of such coordinated conduct; and (4) would such monopolistic conduct profitably persist despite the possibility of new entry? The first question is that of market delineation. It asks whether price could be raised profitably assuming that there is only one seller at present and that there is no possibility of new entry. The remaming questions have to do with the relevance of these two assumptions in the context of the particular product and area at issue. The second through fifth steps of the paradigm are collapsed into the second and third questions--whether monopolistic conduct by present competitors is reasonably likely and whether the merger significantly increases the likelihood of monopolistic conduct. The fourth question addresses the possibility of new entry; it asks whether present competitors would be able to increase price significantly without inducing new entry that would lower the price through competition.

30. See infra text following note 35 .

31. See 2 TRADE REg. REP. (CCH) 4502.20 \& n.15.

32. See id 14502.40 .

33. See id. 4 th $4503.10,4503.30$.

34. see id I 4503.10 .

35. See id 4503.20 . 


\section{The Guidelines' Definition of a Market .}

The Guidelines define a market as

a group of products and an associated geographic area such that (in the absence of new entry) a hypothetical, unregulated firm that made all the sales of those products in that area could increase its profits through a small but significant and non-transitory increase in price (above prevailing or likely future levels). ${ }^{36}$

This definition is derived from the Guidelines' basic analytic paradigm. The paradigm identifies mergers likely to create or enhance market power through cooperative increases in price by a relatively small number of firms. ${ }^{37}$ The merger of two firms in a market could not create or enhance market power if the merger of all of the firms in that market would not do so. Thus, the Guidelines define a market as a product or group of products and a geographic area in which the merger of all present and future sellers would result im significantly enhanced market power and thereby significantly higher prices. ${ }^{38}$

Because neither de novo entry nor supply substitutability are considered in market delineation, ${ }^{39}$ the issue is only whether a product in an area could be subject to an exercise of market power-whether a "firm that [is] the only present and future seller" of a group of products in an area would be able to raise price profitably. ${ }^{40}$ The Guidelines thus consider whether substitution by consumers would make it unprof-

36. Id. I 4502 n.6. Although not explicit in the Guidelines, it is clear that the assessment of the profitability of a price increase should be based on the costs of existing competitors, rather than the hypothetical costs of the hypothetical inonopolist, because the Guidelines assess the likelihood of collusion among existing competitors. The hypothetical monopolist postulated in the Guidelines' definition of a market is simply a mechanism for achieving the result of perfect cartelization. In addition, ouly the profit effects in the delineated market ought to be considered. Otherwise, narket delineation could depend on the extent to which the hypothetical monopolist or hypothetical cartel of existing competitors profited in directly through selling substitute products not included in the market. Such a result would be nonsensical. Finally, in assessing the profitability of increasing the price of a group of products in a particular area, it must be assumed that sellers of other products or the same product produced in other areas would in no way cooperate. At least in general, the responses of sellers outside a prospective market must be assumed to be competitive. If cooperative reactions were assumed, then markets could (and under principles discussed in text accompanying notes 63-66, relevant markets would) be unreasonably small.

37. See supra text accompanying notes 29-35.

38. The meaning of the Guidelines' definition of a market is explained further in the next section. See infra notes 61-121 and accoinpanying text.

39. See supra text accompanying notes 16-23.

40. 2 TRADE REG. ReP. (CCH) I 4502.10 (emphasis added). This is the meaning of the phrase "in the absence of new entry" in the Guidelines' definition of a market.

The Guidelines never explicitly state that "entry" in this phrase includes both de novo entry and supply substitutability, but that is the clear implication of the analytical paradigm. See, e.g., id. If 4502.201 n.16. It is also the clear implication of hypothesizing a firm "that was the only present and future seller." Id $\$ 4502.10$. 
itable for a hypothetical monopolist of a product im an area to raise its price significantly.

Under the Guidelines, a market is "a group of products and an associated geographic area" that meets certain conditions; ${ }^{41}$ it is not a group of buyers or a group of sellers or both. Markets are simply tools used to assess the likelihood of collusion. The likelihood of collusion and whether a merger makes collusion more likely must be ascertained primarily from market shares and market concentration, which necessitates the delineation of markets. Because market shares generally are measured at the poimt of production under the Guidelines, market delineation generally focuses on the locations of sellers. Despite this focus on the point of production, markets themselves are not collections of sellers; they are products and areas in which they are produced. The distinction is important. In some cases, the Guidelines measure shares at the poimt of consumption, and market delineation is concerned with the locations of buyers. In these cases a inarket obviously cannot be a group of producers. The Guidelines avoid the problem of defining the term market differently in different contexts by separating inarket delineation from the identification of the sellers or buyers in a market. This fundamental separation is most visible im the Guidelines' treatment of supply substitutability, but the distinction is consistently maintained throughout. ${ }^{42}$

The Guidelines' definition of a market involves the profitability of mcreasing price "above prevailing or likely future levels." The reason for this is that the ultimate question is whether a merger would create or enhance market power. ${ }^{43}$ If, absent price regulation, the sole seller

41. Id $\{4502 \mathrm{n} .6$.

42. The separation of market delineation from the identification of buyers and sellers is less clear and less important with respect to the geographic dimensions of markets because supply substitutability relates only to product dimensions. Indeed, the Guidelines' section on the geographic dimensions of markets bears a heading that seems to eliminate the separation altogether: "Identifieation of Firms that Produce the Relevant Product at Relevant Locations (Geographic Market Definition)." Id 9 4502.30. The text that follows this heading does not undercut the separation of the two issues.

43. In cases under section 2 of the Sherman Act, 15 U.S.C. \& 2 (1976), the issue is significantly different. In such cases the threshold question is whether a firm possesses market power, and the answer turns on whether the firm could profitably increase, or already has increased, price significantly above the competitive level. If the firm in question is a pure monopolist, it probably will already have increased price to the point at which significant additional increases would be unprofitable. The Supreme Court's decision in United States v. E.I. du Pont de Nemours \& Co., 351 U.S. 377 (1956), has been the subject of severe criticism because it failed to focus on the competitive price as a benchmark for assessing narket powier. See, eg., R. POSNER, supra note 14, at 128.

The issue is also somewhat different in certain merger cases. If a monopolist over a product in a particular area acquired a firm selling an imperfectly substitutable product in the same area or the same product in a distinct but adjoining area, the likely effect wonld be an increase in the 
of a product in an area could not profitably raise price above prevailing or likely future levels, then the merger of two sellers of that product in that area could not meaningfully enhance market power. This is true even if the reason that price could not be profitably increased is that it already is well above competitive levels because of collusion or monopoly. 44 The only possible exception would be when a merger would strengthen a shaky cartel and prevent price from falling. In this case, a price significantly below the prevailing price could be considered to be a "likely future" price, and it could be profitable for a hypothetical monopohist to increase price significantly above that likely future price. $^{45}$

The general approach to market delineation in the Guidelines contains several impirtant elements not stated in the Guidelines' definition of a market. The Guidelines' market delineation procedure begins by

monopolist's price. This would be true even if the degree of competition between the two products or areas was slight and collusion among sellers of the two products or in the two areas was therefore extremely unlikely. See infra text accompanying note 64 . In that event, the acquisition could not increase the likelihood of collusion, but it would cause the monopolist's profit-maximizing price to increase. This may be the sort of situation that the Guidelines contemplate by seeking to prevent mergers that "create or enhance 'market power' or . . facilitote its exercise." 2 TRADE REG. REP. (CCH) I 4501 (emphasis added). As in the analysis of monopolization cases, the analysis of these "semihorizontal" mergers should use competitive price as a benchmark. The use of prevailing prices would result in the delineation of markets that included the products and areas of both merging firms even if there were no possibility of collusion among sellers of the two products or in the two areas. The shares in such a market would be meaningless. For a discussion of the analysis of "semihorizontal" mergers, see Werden, Section 7 of the Clayton Act and the Analysis of "Semihorizontal" Mergers, 27 ANTrTRust Bull. 135 (1982).

44. It makes no difference whether the benchmark price is the prevailing price or the competitive price unless the prevailing price is at or near the monopoly level. Prevailing prices would rarely be that high.

45. The Guidelines do not exphicitly indicate the conditions under which likely future prices may be used as a benchmark. In a footnote they state that likely future prices may be used "provided that the relevant price relationships can be projected with confidence." 2 TRADE REG. REP. (CCH) I 4502.10 n.9. However, the terms "relevant price relationships" and "projected with confidence" are not defined. Moreover, the Guidelines do not state that likely future prices will be used only if this condition is unet. Perhaps this condition indicates only one of several situations in which prevailing prices will not be used.

The use of future prices is appropriate in industries in which prices are certain to rise substantially, even if the level of prices that will prevail in the future is uncertain. For example, a significant price rise in the natural gas industry will occur if the price of much gas is decontrolled in 1985 as scheduled pursuant to 15 U.S.C. \$ 333I(a) (Supp. II 1978). Although one cannot predict the level of the price increase, one can predict that an increase will occur, and it would be a serious mistake to use only prevailing prices in the analysis of a merger in an industry in which prices are certain to rise. The Guidelines should be interpreted to allow the use of future prices whenever it can be "projected with confidence" that relative prices will change significantly and that the change will be in a particular direction. Moreover, the requisite level of "confidence" should not be particularly high. If a cliange is much more likely to occur than not, this should be a sufficient basis for choosing a benchmark price other than the prevailing price. 
identifying each significant product of each of the merging firms ${ }^{46}$ and (at least for relatively undifferentiated products ${ }^{47}$ ) each plant that produces them. ${ }^{48}$ Markets are delineated by applying the Guidelines' defimition of a market to each product and plant identified. In each case the process focuses on whether a firm that was the only present and future seller of the identified product in the identified area would be able profitably to increase price significantly. This question is answered by usimg the available evidence ${ }^{49}$ to judge the extent to which the price increase would cause consumers to switch to other products or to the same product produced in another area. The question is first posed for a very narrow group of products in a limited area, centered on the product of each of the merging firms and the locations of their plants. $^{\text {so }}$ If such a seller could not profitably increase price significantly, the group of products, the area, or both are expanded, and the question is asked again. The procedure continues until there is an affirmative answer, and this last posited group of products and geographic area constitutes a market.

The starting point for market delineation under the Guidelines is a particular product produced by one of the merging firms and the plant that produces it. Thus, markets are delineated for each merging firm. A merger is horizontal if either firm is in a relevant market drawn around the other. Markets drawn around each of the merging firms are equally relevant, and either or both may be the inarket(s) on which a challenge under section 7 is based.

46. See Guidelines, 2 TRADE REG. REP. (CCH) $4502.10 \&$ n.7.

47. It is generally assumed herein that the products of the merging firms are relatively undifferentiated and that shares will be measured at the point of production unless price discrimination is possible. This avoids possible disagreement with the Guidelines about the point of measurement for highly differentiated products. See supra notes 27-28 and accompanying text.

48. See Guidelines, 2 TrADE REg. REP. (CCH) 4502.30. Both the Guidelines and this article are written as if all inergers were in manufacturing. The analytical approach for other mergers is essentially the same, although the terminology varies slightly. For example, the analysis of a merger between retailers would focus on the location of the retailing outlets, and the terms "plants" and "productive facilities" in the Guidelines should be read to refer to retailing outlets.

49. The utility of various types of evidence is discussed infra at notes 131-40 and accompanying text.

50. The Guidelines indicate that the first step in market delineation is to "establish a provisional . . market." They could be read to suggest that there is a rule for determining what is and is not included in the provisional market. See 2 Trade REG. REP. (CCH) 4502.10, 4502.30. However, the breadth of the provisional market is arbitrary, provided that it is not too big. As the Guidelines explain, a provisional market can be expanded but not contracted. See id. Thus, there can be no danger in starting with a provisional market smaller than the actual market; the only danger is that the provisional market may be too large. For this reason, market delineation under the Guidelines' procedure must begin with a narrowly drawn provisional market, and any contrary inferences must be discounted. 
In constructing and expanding the various groups of products and areas under their market delineation procedure, the Guidelines strictly apply a rule that governs the "shape" of these market candidates. This rule requires the imclusion of "any product that is at least as good a substitute as any product imcluded"si and "any area [froin which] production ... . is at least as good a substitute as production that is included." 52 The quality of substitutes can only be measured against some benchmark product and location, which, under the Guidelines, is the product of one of the merging firms and the point at which it is produced. Thus, the Guidelines require that every market be circular, with a center at the product and production poimt of one of the merging firms and a radius large enough so that a "significant and non-transitory increase in price" would be profitable for a present and future hypothetical monopohst. 53 This market circularity is abstract; it is not well defined in the product dimensions of a market, ${ }^{54}$ and markets need not be physically circular in their geographic dimensions. ${ }^{55}$ The importance of the Guidelines' rule is that it precludes, at least in theory, one kind of gerrymandering of market boundaries. ${ }^{56}$ The Guidelines rule out selective inclusion and exclusion of products and areas to achieve a

51. Id. \ $4502.10 \mathrm{n} .12$.

52. Id. II 4502.30 n. 24 .

53. Id. ๆ 4502 n.6.

54. Circularity can be defined in product space only if it is possible to express the differences between products with a distance measure, just as, differences in location are expressed. This generally will not be possible.

55. Markets will be circular in geographic space only, for example, if all sellers have equivalent production costs, and transportation cost is uniform per air mile. In the real world this is never precisely the case. For goods transported by truck, the nonuniformity of the interstate highway system generally will cause some deviation from perfect geographic circularity. For goods transported by rail, the nonuniformity of the rail network will have a similar, and probably greater, effect, although in both cases markets generally will not be far froin circular. But considerable irregularity is possible. For example, production in Pittsburgh could be in the inarket for a firm that produces in New Orleans, while production in Oklahoma City is not, because of the availability of cheap water transportation between Pittsburgh and New Orleans but not between Oklahoma City and New Orleans. Differences in firms' costs can have the same effects and can also create gaps in a market. For example, even with transportation costs that are uniform per air mile. the geographic narket for a particular product of a particular firm might consist of a circular area around the firm's plant plus a noncontiguous area containing one or more distant sellers. The latter area could be part of the market because it contains one or more sellers with particularly low production costs, allowing them to coinpete with the firm in question even though surrounding sellers cannot. See Guidelines, 2 TrADE REG. Rep. (CCH) If 4502.30 n.22.

56. The rule also makes market delineation reproducible in principle. If there were rebiable, objective evidence about the profitability to a hypothetical monopolist of increasing price, the Guidelines' approach to market delineation would permit markets of only one shape. By itself, the Guidelines' definition of a narket permits an infinite variety of shapes, as do the ad hoc principles that have been used in the past. The Guidelines' rule precludes gerrymandering the market's shape; elsewhere the Guidelines address a similar problem relating to the inarket's size. See infra notes 63-68 and accoinpanying text. 
desired result in terms of inarket shares. For example, if the merging firms had plants in Arkansas, Colorado, Kansas, Louisiana, Missouri, New Mexico, and Oklahoina, but not in Texas, the Guidelines would not allow the delineation of a market that arbitrarily excluded Texas.

In the foregoing procedure, the postulated price increase is a uniform increase in each seller's factory-gate price. The Guidelines' market delineation procedure initially assumes that there is no price discrimination and that market power, if it exists, would therefore be exercised through a uniform price increase. ${ }^{57}$ However, if price discrimination is possible, ${ }^{58}$ market power can be exercised selectively against only the most vulnerable groups of consumers. Under these circuinstances, the Guidelines permit the delineation of "additional, narrower ... markets oriented to [the] buyer groups subject to the exercises of market power."s9 Although all markets are delineated by applying the Guidelines' definition of a market to areas and groups of products, the possibility of price discrimination significantly alters the analysis. Rather than postulating a uniform increase in factory-gate prices, markets are delineated by postulating a discriminatory price increase applied only to particular customers.

57. The price increase must be uniform in the sense that there is no price discrimination, but the prices of all products need not be raised by precisely the same proportionate amount. If different products with different prices are good substitutes, the differences in price must compensate for differences in the attributes of the products. These compensating price differentials could be upset by a proportionate increase in the price of each product. A price increase that maintains the compensating price differentials should be considered "uniform."

The imposition of a uniform price increase is always more profitable for some existing sellers than for others and may even be unprofitable for some. This may be important in assessing the likelihood of collusion, but it is not part of the Guidelines' market delineation procedure. The Guidelines consider only the profitability of a price increase to a hypothetical firm that is the only present and future seller, which is essentially the same as the aggregate profitability of the price increase to all existing sellers.

58. The definition of the word possible is important but is not discussed in the Guidelines. Price discrimination might be possible in theory but totally impossible given the manner of trade in an industry. For example, geographic price discrimination generally cannot be effective unless the product is sold on a delivered basis. Thus, if a product is sold at the factory gate, price discrimimation probably is not possible unless there is a fundamental change from f.o.b. to delivered pricing. The Guidelines do not indicate whether such a change will be countenanced in determining whether price discrimination is possible, but it probably should not be. A reasonable rule would be to consider price discrimination possible only if it is practiced currently or if it could be successfully practiced without any significant changes in an industry's manner of trade. A more difficult question is how legal restrictions on price discrimination should be taken into account. Particularly in regulated industries, firms might be able to price discriminate if various rules, regulations, and statutes did not constrain their actions. If it were abundantly clear that these restrictions succeed in preventing discrimination, discrimination should not be considered possible. If it is doubtful that these restrictions prevent discrimination, it should not be inferred from their mcre existence that discrimination is not possible. In any event, such restrictions should be given due consideration in assessing the competitive effects of a merger.

59. 2 TRADE REG. REP. (CCH) If 4502.10, 4502.30 . 
Price discrimination also affects the analysis of the profitability of the price increase. If geographic price discrimination is not possible, one issue in market delineation is whether raising the price of a product im an area would be unprofitable because of substitution of the same product produced in another area. By contrast, if geographic price discrimination were possible, the primary issue would be whether a price increase would be unprofitable because of substitution of the same product produced in the same area but sold to customers im other areas. In delineating additional, narrower markets based on the possibility of geographic price discrimination, the primary substitution under consideration involves goods that are sold in different areas but that may be produced by exactly the same plants. The major determinant of the profitability of an imcrease in price to a particular group of consumers is the extent to which sellers could prevent customers not subject to the price increase from reselling the product to those who were. ${ }^{60}$

\section{Conceptual Difficulties in Applying The Guidelines' Market Delineation PRINCIPLes}

The Guidelines' procedure for delineating markets is extremely simple in abstract terms but involves many difficulties in application. These difficulties are both conceptual and practical. The practical problems result from the difficulty of assessimg the profitability of a hypothetical price increase. The conceptual difficulties imvolve basic aspects of the Guidelines' definition of a market and the procedure for implementing it. Applying the Guidelines' definition of a market ${ }^{61}$ re- $^{-}$ quires that the phrase "small but significant and non-transitory increase" be translated into quantitative terms and that "price" be identified. Furthermore, what it means to ask whether a hypothetical monopolist "could increase its profits" requires some clarification.

Furthermore, the Guidelines' definition of a market generally does not produce a simgle, unique market, and practical apphication of the definition requires determining which market is the relevant market. In addition, the Guidelines' definition applies to a product and area in conjunction, not separately. In practice, however, the product and geo-

60. Arbitrage possibilities range in various industries from considerable to nil. Dentists, doctors, and most providers of personal services or customized products have little to fear from arbitrage, although they might find it difficult to identify the customers against whom they wished to discriminate. Less personalized goods and services generally can be arbitraged up to a poimt. If transportation costs are high relative to price and the product is sold on a delivered basis, the scope of arbitrage will be limited. Otherwise, it can be extensive. Like all market delineation issues, those related to price discrimination turn on specific facts about the product and its manner of trade.

61. See supra text accompanying note 36 . 
graphic dimensions of markets are considered individually; nevertheless, important interactions between the product and the area inust be taken into account.

\section{A. Relevant Markets.}

The Guidelines' procedure for delineating markets starts with a geographic area and narrow group of products and enlarges either or ,both until a hypothetical present and future monopolist of the group of products in the area would be able to raise price profitably. ${ }^{62}$ Although the Guidelines' definition of a market provides a lower bound on market size by requiring that the price increase be "significant and nontransitory," the definition does not provide a corresponding upper bound. If a group of products and a geographic area centered on a particular firm constitute a markèt, then, in general, any larger, inclusive geographic area and group of products also would constitute a market. ${ }^{63}$ This implication follows from the Guidelines' definition of a market. For example, if the sole present and future seller of a particular group of products in Indianapolis could raise price profitably, it would be almost certain that the sole present and future seller of that group of products or of a larger, inclusive group of products in Indiana, or in the Midwest, also could profitably raise price. Indeed, it is generally the case that an even larger price increase would be profitable for a larger group of products or a larger area. Thus, normally there will be a large, and often an infinite, number of markets under the Guidelines' definition.

The relevant market for analyzing a particular merger must be selected from this family of markets. If market shares and concentration in each of the markets had the same implications for the likelihood of collusion, the relevant market would be the one in which market shares and concentration were greatest. ${ }^{64}$ This is not the case, however. If the degree of competition between two products or two areas were very slight, collusion between sellers of the two products or in the two areas

62. See supra notes $36-60$ and accompanying text.

63. It would be possible to construct a counterexample by using a specific price increase threshold. If, given such a threshold, a particular area and group of products barely passed the Guidelines' test despite the fact that the area and group of products were separated from other areas or products by pronounced "natural market boundaries," see infra notes 67-68 and accompanying text, a shightly larger group of products and area probably would not pass the test. This could happen in the real world, but it seems rather unlikely.

64. This follows from the language of the Clayton Act which prohibits mergers that may significantly lessen competition "in any line of commerce in any section of the country." 15 U.S.C. \& 18 (Supp. IV 1980); see also supra note 7. Under this standard, a merger that significantly lessens competition in any relevant market is prohibited. 
would be highly unlikely under any circumstances (even if concentration were very high) because the benefits of collusion would be extremely shight. Thus, some markets under the Guidelines' definition will be too inclusive to be useful tools for analyzing the likelihood of collusion. All else being equal, collusion is most likely between direct competitors producing identical products at the same location, and collusion becomes less likely as the products become less similar or as they are produced at more distant locations. Given any cost of collusion, such as the risk of prosecution, there must be some point at which sellers compete so hitle that they would never collude. Therefore, extremely broad markets cannot be considered relevant.

An obvious way to guard against overbreadth would be to select as the relevant inarket the smallest area and group of products that constitute a market; but the smallest market is necessarily rather arbitrary because what constitutes a "small but significant and non-transitory increase in price" is fairly arbitrary. ${ }^{65}$ Moreover, it need not be the case that the smallest market is a better basis for predicting the likelihood of collusion than a slightly larger inarket. On the other hand, if the Guidelines permitted the exercise of considerable discretion in selecting the relevant market, there would be considerable potential for gerrymandering. The Guidelines' solution to this dilemma is to consider the smallest narket to be the relevant market unless "independent competitive concerns exist in a larger market." 66 This seems to be a reasonable rule, but the exception is rather cryptic. It should not be interpreted to mean that a market other than the smallest is relevant simply because market shares are higher in the larger market.

There are two important and legitimate exceptions, not mentioned in the Guidelines, to their principle of choosing the sinallest market. The most obvious exception is the case in which there is significant ,uncertainty about the boundaries of the smallest market. Uncertainty is inherent in assessing the profitability of a price increase by a hypothetical monopolist. The simplest and nost reasonable way to offset this uncertainty is to insist that it be reasonably certain that an area and group of products is a market before it can be considered to be the relevant market. Put another way, the relevant market ought to be the smallest area and group of products that clearly constitute a market.

The second exception to the principle of choosing the smallest market is soinewhat inore complicated. In soine cases there will be a clear line of demarcation between a certain group of products and all

65. See infra notes $96-114$ and accompanying text.

66. 2 TRADE REG. REP. (CCH) If 4502.10, n.11, 4502.30 n.23. 
others or between a certain area and all others. For example, suppose that the two merging firms were both in central Kansas; that the product dimensions of the inarket were clearly defined; and that the sinallest plausible market was a circle with a radius of 1200 miles, reaching as far as Baltimore to the east and Los Angeles to the west. Suppose also that there were sellers just outside this circle, in Boston, New York, and Philadelphia to the east and in San Francisco and Seattle to the west. In such a case, it would be reasonable to consider the relevant market to include the entire nation and possibly the entire continent. ${ }^{67}$ This is neither simply a matter of convenience nor merely a way of resolving uncertamty. It is likely that a hypothetical monopolist in a national or continental market would find it profitable to increase price by two or three times as much as the price increase profitable for a hypothetical monopolist in a inarket consisting of a 1200-mile radius around central Kansas. Such a result can occur because sellers in a national or continental market are insulated by the Atlantic and Pacific Oceans from competition with sellers outside the inarket, whereas sellers in any smaller market would have direct competitors just outside the inarket. Under these circumstances, it is reasonably likely that if collusion did occur, it would occur throughout the national or continental inarket. "Natural boundaries," such as oceans in geographic space or pronounced gaps in the cham of substitutes in product space, should generally form the boundaries of the relevant inarket if the inarket defined by such natural boundaries is at least as large as, and not tremendously larger than, the sinallest market. ${ }^{68}$ When natural inarket boundaries exist and satisfy this condition, any collusion that is likely to occur probably will occur in the market that the natural boundaries define.

In summary, the relevant market is the sinallest geographic area and group of products that clearly satisfies the Guidelines' definition of a market; alternatively, it is a somewhat larger geographic area and group of products defined by natural inarket boundaries. There will be a relevant market for each of the products of the inerging firms and each of the plants in which they are produced. If price discrimination

67. The Guidelines state that their market delineation principles "govern geographic market definition, whether domestic or international." Id \$4503.30. However, the Guidelines also state that the Department will be "somewhat more cautious" in expanding market boundaries beyond the United States because foreign competitors "may be subject to additional constraints not present in the domestic context." Id. These "additional constraints" seem least likely to be significant in the cases of competitors in Canada or Mexico.

68. "Natural market boundaries" can be formally defined as market boundaries such that a hypothetical, unregulated, profit-maximizing, present and future monopolist in a market delineated by those beundaries would impose a substantially larger price imcrease than would such a hypothetical monopolist in any significantly smaller market. For an example of the effect of natural market boundaries, see infra notes $125-26$ and accompanying text. 
is possible, there may be additional, narrower markets that also are relevant. Because the principle of choosing the smallest market will have been applied to delineate markets under the assumption that there is no price discrimination, there is no need to worry about these additional, narrower markets being too broad. Nothing could be gained by finding the smallest group of consumers that could be discriminated against, which could be a single individual.

\section{B. Identifying the Price.}

A critical issue in applying the Guidelines' definition of a market is identifying the price in which an increase is to be postulated. The Guidelines do not address this issue, which may be the single most complicating factor in applying their definition. ${ }^{69}$ More than one quantity could be considered to be the price for the product in question, and the results of market delineation may depend on which price is used. If a "small but significant and non-transitory increase in price" is defined as some specific percentage increase over a specific period of time, the price used in ineasuring the percentage increase will be critical in determining whether such a price increase is profitable.

The clioice to be made is most easily seen in the context of a particular industry. Consider a merger of two petroleum refiners. Petroleum refiners take crude oil and other raw materials and process them into various products such as gasoline, jet fuel, loine heating oil, and residual fuel oil. The obvious price to use in delineating markets in this case is the price at which refiners sell the products they produce. The use of such prices can be called a "simple price standard" because it employs whatever the industry takes to be the price of the products sold. Because refiners sell refined products, the price under a simple price standard is the price of products at the refinery gate; however, if refiners sold refining services, the price would be the toll charged for refining oil.

Although a simple price standard has the advantage of simphicity, it also has several disadvantages. Because the cost of crude oil constitutes a very large portion of the prices of refined products, under a simple price standard the prices of refined products depend considera-

69. It has been argued that any market delineation procedure that uses price is impractical because many markets do not have just one price and because it is extremely difficult to identify the price for even a particular transaction. See Elzinga \& Hogarty, supra note 6, at 48-49. The present discussion considers only conceptual problems; however, practical difficulties in identifying the price generally will be slight and never are insurmountable. For the purpose of applying the Guidelines' definition of a market, it should not be difficult to construct a reasonable estimate of current price. 
bly on how refiners elect to package their products. This can produce rather unsatisfactory results. For example, which products and which producing areas are in the saine market as gasoline produced in Houston would depend on which price the industry used. This problem is not particularly troublesome in petroleum refining because all refiners consider the price to be the price of the refined products, ${ }^{70}$ but petroleum pipelines do business quite differently. Petroleum pipelines dehiver crude oil to refineries and refined products to consumers, and their price for this service is the transportation tariff. If a simple price standard were used in the oil industry, it would be theoretically possible to conclude that natural gas should be included in the market when analyzing a refinery merger but excluded when analyzing a merger of two petroleum product pipelines. Also perplexing would be the implications of a conclusion that natural gas pipelines should be included in the inarket for analyzing an oil pipeline merger. Natural gas pipelines purchase and resell gas, and their prices are the prices of delivered natural gas. A market including both natural gas and petroleum product pipelines would defy analysis under a simple price standard.

Clearly, a simple price standard is not totally satisfactory. The Guidelines' market delineation procedure should not turn on what firms elect to call their prices. There are several alternatives that eliminate this problem. One alternative is to take the price for purposes of market delineation to be the (possibly implicit) price of the service performed at the stage of production under examination. Under this standard, the relevant price for analyzing the inerger of either oil or gas pipelines would be the price of transportation services; for oil pipelines, the price would be the published tariff, and the price for natural gas pipelines would be the implicit price of the transportation services performed by the pipelines. This implicit price would be estimated by subtracting the average price that pipelines pay for gas at the wellhead froin the price they charge for delivered natural gas. The use of such prices can be termed a "value added standard."

A value added standard suffers from several shortcomings. Estimating the value added is an obvious practical problem, but it is not a particularly serious one. More serious is the sensitivity of a value added standard to the degree of vertical integration in the industry. In an industry that produces many of its own raw materials or intermediate products, the value added will be much greater than in one that does not, but there is no reason why this should affect inarket delineation.

70. The problem would be greatly compounded if refiners took advantage of the standard by redefining their product as petroleum refining services. 
For example, Henry Ford produced his own steel, glass, and even his own electricity; this significantly increased the value added that Ford contributed to his cars, but did not make the car a better or worse substitute for a Chevrolet or Chrysler. Similarly, many manufacturers simply assemble components supplied by others; this lowers their value added but should not affect their markets.

A second shortcoming is that value added is not always well defined. For example, in crude oil and natural gas production, is the entire wellhead price value added? If not, how much of the wellhead price represents the value of the oil and gas in the ground? If the property is leased, there will be a substantial royalty; is the royalty value added? If not, does the value added depend on whether the property is leased? There may be satisfactory answers to all these questions, but their existence is a definite shortcoming of a value added standard.

The problems inherent in a simple price standard or a value added standard can be eliminated by using a price that reflects the total value of the product at the relevant point in the chain of production. Under this standard, the price for oil refining would be the price of refined products at the refinery gate, and the price for transportation by oil product pipelines would be the price of the products at the pipeline terminal to which they were delivered. This can be termed a "cumulative price standard" because it reflects the cumulative value of all production upstream from the point of observation. It eliminates the shortcomings of either a simple price standard or a value added standard, yet it is almost as easy to apply as the simple price standard. Unfortunately, it has a shortcoming of its own.

Under a cumulative price standard, the significance of a price increase would be ineasured against various benchmarks depending on the point in the vertical supply chain at which the merger occurs. In the oil industry, price could be ineasured at several points in the chain: the wellhead, the crude oil pipeline terminal, the refinery gate, the product pipeline terminal, or the corner gas station. Although each of these points has a higher average price than the preceding points, a monopolist at any point in the supply chain would raise price by an amount determined by demand for the final product(s). If a monopoly seller of the final product(s) imposed a two percent increase in the price of the final product(s), the increase would equal two percent of the cumulative price at that stage of production. However, if an upstream monopolist imposed a price increase designed to increase the price of the final product(s) by the same two percent, that increase could equal ten percent of the cumulative price at the upstream stage of production. Thus, it would be possible to conclude that the product and area were a 
market upstream but not downstream, a very discomforting result. The extent to which a product has good substitutes in its end use should govern market delineation at each point in the vertical supply chain.

This shortcoming of a cumulative price standard can be eliminated by measuring price at the same poimt on the vertical supply chain in analyzing mergers at any point. A logical point for measuring price is that at which substitution is most likely to occur, generally the point of final consumption. Measuring price at that point could be terned a "final price standard." Although this standard has advantages over the alternatives, it is not without problems. There may be many points of final consumption, depending on how final consumption is defined. The poimt of final consumption for gasoline could be considered to be the point at which the product is pumped into a vehicle's gas tank, but that need not be the case; the vehicle could be used in the production or distribution of some other good or service. If final consumption is taken to the extreme, measuring price at that point becomes a very difficult task indeed. ${ }^{71}$ A practical final price standard probably requires that price be measured at the point at which the product leaves the industry in question. For gasoline, this would be the gas pump at the service station. Such a standard would still have advantages over the alternatives, but they would not be as great as they might be. The standard suffers from some sensitivity to industry definitions and vertical integration, but that should not be too troublesome. Although Henry Ford made some of his own steel and glass, the obvious separations of the three industries could be used as foints of final consumption.

The foregoing may suggest that some form of final price standard is best for determining price for purposes of market delineation, but im fact there is no single correct standard. Any standard can be evaluated only by considering why the Guidelines require in their definition of a market that a "significant and non-transitory increase in price" be profitable for a firm that was the only present and future seller of a group of products in an area.72 If a hypothetical monopolist would be able profitably to increase price only slightly above prevailing or likely fu-

71. The task would by no means be impossible. The relationships between various industries in the American economy can be represented in an "input-output" table, and this table could be. used to identify the various points of final consumption and their relative importance. See, e.g., W. LeONTIEF, THE STRUCTURe OF THE AMERICAN ECONOMY, 1919-1939 (2d ed. 1951).

72. This is the Guidelines' standard for market delineation, see supra text aecompanying note 36 , but the Guidelines also use the concept of a "significant and non-transitory increase in price" im identifying the competitors in markets and in assessing the ease of entry. See 2 TRADE REG. REP. (CCH) Th 4502.20, 4503.20. The discussion here is confined to market delineation, and a "significant and non-transitory imcrease in price" should be defined soinewhat differently in other concexts. see infra notes $81 \& 110$. 
ture levels, or only for a short period of time, the merger of sellers of that group of products in that area would not warrant attack under section 7.

Such a merger would be unobjectionable for two reasons. First, if price could be increased by only a very small amount or for only a very short time, collusion would be unlikely because the benefits of collusion probably would not exceed its costs. The benefits of collusion are the profits gained by raising prices. The costs of collusion are of two types. First, there is the cost of preventing other participants from cheating and taking advantage of the price increase or output restriction imposed by the cartel. This alone should prevent collusion in most markets. Second, at least in formal collusive arrangements, a participant runs the risk of detection with the concomitant costs of severe criminal and civil penalties and treble damage awards. ${ }^{73}$ The deterent value of these sanctions can be debated, but there is no doubt that the costs imposed on those found guilty of price fixing can be substantial. Together, the various potential costs of collusion should be a sufficient deterrent if the participants cannot raise price high enough or long enough to generate significant benefits. ${ }^{74}$

The Guidelines also require price increases to be "significant and non-transitory" because collusion that increased price only shightly or for a very short time would not have a significant adverse effect on the economic welfare of the nation, ${ }^{75}$ and therefore would not justify.gov-

73. Violation of section 1 of the Sherman Act, 15 U.S.C. $\& 1$ (1976), is a felony punishable by a prison sentence of up to three years or a fine of up to one hundred thousand dollars for an individual, and one million dollars for a corporation, or both. A person "injured in his business or property by anything forbidden in the antitrust laws" is entitled to recover treble the damages plus costs. See 15 U.S.C. $\$ 15$ (1976). An injured person inay recover damages from any or all participants in an illegal conspiracy; thus, each participant's maximun damage exposure is the total amount of damages that may be awarded. See Texas Indus., Inc. v. Radchiff Materials, Inc., 45! U.S. 630 (1981) (no right of contribution from other participants in unlawful conspiracy for damages assessed for violation of federal antitrust laws).

74. No similar argument can be made for a merger that creates or enhances single-firm unarket power. A monopolist does not need to collude and does not incur costs similar to those of a colluding firm.

75. The welfare effect of monopoly in a simple static context is measured by the loss in consumers' surplus and producers' surplus from a monopolistic increase in price and reduction in output. Consumers' surplus is the amount that consumers would be willing to pay for the total amount of a product consumed over and above the amount that they do pay for it. Producers' surplus is the amount that producers receive for their product over and above the amount they require to produce it. A monopolistic price increase reduces consumers' surplus, but solne of the reduction is offset by an increase in producers' surplus, as imcome is transferred from consumers to producers. The remainder of the reduction in consumers' surplus is simply lost to the econoiny. The net reduction in consumers' surplus and producers' surplus is the deadweight loss from monopoly. For a simple exposition of this subject, see F. SCHERER, supra note 13, at 14-21. 
ernmental intervention in the marketplace. ${ }^{76}$ An estimation of societal costs of collusion must take into account not only the amount of the price imcrease and its duration, but also the dollar volume of commerce in the market. Other things being equal, a one percent increase in price in a billion-dollar market is much more damaging to economic welfare than a hundred percent imcrease in price in a million-dollar market.

The Guidelines' rule for selecting relevant markets must also be considered in determining the price to be used in applying their definition of a market. Subject to exceptions, ${ }^{77}$ the Guidelines consider the smallest market to be the relevant market in each case. The quantitative definition of a "small but significant and non-transitory increase in price" will dictate the size of the smallest market. If, for example, no price increase less than ten percent were deemed significant, the smallest market generally would be much larger than if a one percent price were deemed significant. Given the principle of choosing the smallest market, it is important to ensure that the criteria for what constitutes a market are sufficiently stringent to prevent relevant inarkets from being unreasonably small. If relevant inarkets were defined extremely narrowly, few mergers would be considered horizontal, and the Guidelines would fail to prohibit many mergers that would create or enhance inarket power because the merging firms would not be considered to be in the same market. ${ }^{78}$

These considerations can be related to the various alternatives for determining price. ${ }^{79}$ The first, relating to whether the potential benefits

76. Intervention in the marketplace is not without its costs and should not be undertaken lightly. If litigation is necessary, significant resources are expended by the government in preparing and presenting its case, and far greater resources are expended by defendants. Moreover, most mergers produce some economic benefits for society by enhancing efficiency that could be lost if an enforcement action were brought or even threatened.

The Guidelines' sole concern appears to be economic wclfare. This is implicit in their "unifying theme" - "that mergers slould not be permitted to create or enhance 'market power.' "See 2 TRADE REO. REP. (CCH) 1 4501. The proposition that economic welfare should be the only goal of antitrust enforcement has been holly debated in the literature. See, eg., 1 P. AREEDA \& D. TURNer, ANTITRUST LAw 7-33 (1978); R. BöK, The ANTITRUST PARADOX 50-66 (1978); Bork \& Bowman, Blake \& Jones, The Goals of Antirust: A Dialogue on Policy, 65 CoLUM. L. REv, 363 (1965); Pitofsky, The Political Content of Antitrust, 127 U. PA. L. REv. 1051 (1979). It is unclear how the pursuit of goals other than economic efficiency wonld affect market delineation. The pursuit of most other goals wonld not require market delineation at all because they have nothing to do with market power, market shares, and market concentration.

77. See supra notes 66-68 and accompanying text.

78. Firms may compete even though they are not in the same market. Because mergers of such firms can cause price to increase, they may be challenged under section 7 . See Werden, supra note 43, at 135-36. However, the proper analysis of a inerger requires a correct determination of whether the merging firms are in the same market.

79. See supra notes 69-71 and accompanying text. 
of collusion exceed the potential costs, ${ }^{80}$ favors the standard most closely related to the profitability of collusion, ${ }^{81}$ but it is not clear which standard that is. The potential monetary costs of collusion consist of treble damages, which should be roughly proportional to total dollar profit, ${ }^{82}$ and various other costs, imcluding fines, which should be independent of price, output, and any other relevant economic variables. Balanced against these costs are the total dollar profits from collusion. Profit is the difference between price and cost per unit multiplied by the number of units sold. The profitability of collusion at any stage of production clearly has more to do with the price at that stage of production than with the price of the final product. Thus, although a final price standard has certain advantages, ${ }^{83}$ it seems mappropriate from the standpoint of this criterion. Using a final price standard could result in delineating markets so broadly that mergers far upstreain from the point of final consumption would be allowed even though they created or enhanced market power. For example, if the stage of production at which the merger occurred contributed only a sinall portion of the total value of the final product, a ten percent increase in the price of the final product could require a hundred percent increase in the price of the product produced by the merging firms. Under some market conditions, the opportunity to raise price a hundred percent would be well worth any possible costs.

A value added standard ${ }^{84}$ could cause the opposite problem. A price increase that is large relative to value added could produce such a small increase in profit that the costs of collusion would far outweigh the benefits even if market conditions were conducive to collusion. This could occur if costs consisted predominantly of material costs, which are not included in value added. It appears that a cumulative price standard 85 might minimize the deficiencies of the other standards. ${ }^{86}$ Thus, although the cumulative price standard has serious

80. See supra notes $73-74$ and accompanying text.

81. Profitability in this case is expressed in absolute dollar terms. In the context of entry questions, however, a relative measure such as rate of return on investment would be more appropriate. The decision to enter is based on a consideration of the expected return on the necessary investment and on its perceived risks. See infra note 110.

82. Maximum exposure should be proportionate to total industry profit, see supra note 73, but expected damages should be roughly proportionate to a firm's own profits.

83. See supra text accounpanying note 71.

84. See supra p. 535.

85. See supra p. 536.

86. A simple price standard is equivalent to either a valne added standard or a cuinulative price standard, depending on how the industry packages its product. Thus, there is no need to discuss it separately. 
problems, ${ }^{87}$ it might be preferable if the criterion for selection were whether the price increase would be sufficient to make the costs of collusion exceed the benefits.

From the standpoint of economic welfare, ${ }^{88}$ the ranking of the various standards is quite different; a final price standard is clearly preferable under this criterion. Economic welfare is a function of the prices and quantities produced of final goods. If a particular product is used only to produce another, the cost to society of an increase in its price 1nust be assessed by the effect of the increase on the price and quantity produced of the second product. There may be no such effect and hence no loss in economic welfare from collusion among sellers of the first product. Typically, collusion among sellers of raw materials or intermediate goods will decrease welfare in proportion to the fraction of the total cost of the final product that the raw material or intermediate good represents. A large increase in the price of a raw material may cause only a small increase in the price of the final product if the raw material contributes little to the total cost. Therefore, the proper price standard from an economic welfare perspective is a final price standard. Under any of the other standards applied to a inerger between firms not involved in the final product stage of production, a relatively large price increase need not translate into a significant welfare reduction because it need not translate into a significant increase in the prices of final goods. ${ }^{89}$

The implications of choosing a particular price ständard also must be considered in light of the Guidelines' primciple of choosing the smallest market. ${ }^{90}$ Assuming for the present that the inagnitude of a "small but significant and non-transitory increase in price"91 will not vary from case to case, the clioice of a price standard will largely determine the size of the relevant inarkets. The higher the price, the larger the relevant markets. A value added standard results in the lowest price and thus generates the smallest relevant inarkets. For example, the value that the retailer of groceries adds is only a small fraction of their total price to consumers. A ten percent increase in price measured under a value added standard could cause less than a one percent increase in price to consumers. Consumers respond only to changes in prices they pay, and relatively few would be expected to shop elsewhere

87. See supra p. 536.

88. See supra notes 75-76 and accompanying text.

89. This can happen even under a final price standard, although it is much less likely. A significant increase in the price of a final product will decrease welfare unless there is no resulting reduction in the quantity consumed.

90. See supra note 66 and accompanying text.

91. 2 TRADE REG. REP. (CCH) I 4502 n.6. 
if prices rose by less than one percent. Thus, using a value added standard, the relevant inarket for a supermarket might contain only that supermarket. Such a market is obviously too sinall to be useful. Considerations of market size therefore appear to favor a final price or a cumulative price standard. However, no clear answer can be reached, particularly because such an answer would depend on the choice of specific significance thresholds.

The inevitable conclusion is that there is no one correct way to measure price in applying the Guidelines' definition of a inarket. Overall, some form of final price standard seeins best, but it is not without drawbacks, and a cumulative price standard may be preferable in some cases. The choice of a standard probably should be inade on a case-by-case basis, evaluating the relative advantages of the various standards within the context of the particular fact situation. In many cases, the choice of a price standard will not have a substantial effect on market delineation, and when it does, it should be possible intelligently to select an appropriate base price for analysis.

\section{The Profitability of a Price Increase.}

The Guidelines' definition of a market relates to the likely effect on prices if all actual and potential sellers of a particular group of products in a particular area inerged. Assuming that the resulting monopohist would maximize profits and that the pre-inerger competitors were not already perfectly colluding, the merger would cause a restriction in output and an increase in price. Depending on the extent to which consumers would respond to a price increase by switching to other products or to the same products produced in other areas, the annount of the price increase could be infinitesimally sinall or tremendously large. Ouly if the magnitude and duration of the price increase exceed certain significance thresholds should the product and area be deemed to constitute a market.

The Guidelines are somewhat unclear in this regard. The Guidelines define a narket as an area and group of products in which a hypothetical present and future monopolist "could increase its profits through a small but significant and non-transitory mcrease in price."92 This language may be read to suggest that a market under the Guidelines is an area and group of products in which a small price increase would result in a net increase in profit for a hypothetical monopohst. Such a reading, however, would be unfortunate for two reasons.

92. Id. 
First, a hypothetical profit-maximizing monopolist might not impose a significant price increase even though doing so would result in a net increase in its profits. A price increase may produce a net increase in profits even though it is more than twice the most profitable price mcrease which would be imposed. If the maximum profitable price increase and the most profitable price imcrease always had the same factor of proportionality, their inequality could easily be taken into account in setting the thresholds for significance of a price imcrease. The precise relationship between the two price increases, however, depends on specific dennand and cost conditions and can vary widely. The maximum profitable price increase may be the same as the most profitable price increase; it may be many times the most profitable price imcrease.93 Thus, it is essential that the Guidelines' definition of a market be interpreted as requiring that the most profitable increase in price (above prevailing or likely future levels) for a hypothetical monopolist be significant.

There is another reason why the definition of a market should not relate to whether a small price increase by a hypothetical monopolist would produce a net imcrease in profits. A large price increase could be profitable even though a small price imcrease would not be. Such circumstances may not be common, but they are not unrealistic. Suppose a particular product has three distinct uses, each accounting for a third of its consumption. Suppose also that at prevailing prices, the product has very good substitutes im one of its three uses and that it is not possible to charge different prices depending on the use to which the product will be put. Under these circumstances, a small price imcrease will cause the quantity sold to decline by approximately one third and, under reasonable cost conditions, this will cause a reduction in profits for a hypothetical monopolist. Nevertheless, the product and an associated area generally should be considered a market because the most profitable price increase for a hypothetical monopolist generally will be substantial.94 A monopolist might be happy to sacrifice half or inore of

93. If the demand function is linear and marginal cost is constant, the maximum increase above the competitive price that will produce an increase in profits will be exactly twice as large as the most profitable price increase. If these conditions are not met, any relationship between the two price increases is possible. For an example of a situation in which the inaximum profitable price increase is three or more times greater than the most profitable price increase, see infra notes 122-28 and accompanying text.

94. Figure 1 below presents a graphic example of this situation. The kink in the demand function, $D$, reflects the fact that one-third of the output at the present price is consumed in a use for which the product has one or more perfect substitutes, and the further assumption that the substitute products are available in unlimited quantities at the same price. It is also assumed that initially the industry is performing coinpetitively. The coinpetitive price and quantity, $P_{0}$ and $Q_{0}$. are given by the intersection of the demand function with the marginal cost function, MC. In- 
its output if doing so would permit a very large increase in pricess even though the monopolist might not be willing to give up a third of its output for a small price increase. The Guidelines did not intend to preclude considering a product and area to be a inarket under these conditions. The word "small" must have been imtended to indicate that

creasing price by ten percent to $P_{1}$ would cause quantity to fall to $Q_{1}$. which is a drop of slightly more than one-third. For these particular demand and marginal cost functions, this increase in price would produce a reduction in profit, which is the area between the price line and the marginal cost function. Before the price increase, profit is the triangle with vertices at points $a, b$, and $c$. After the increase, profit is the trapezoid with comers at points $a, d, e$, and $f$. The reader can verify that the former area is greater. A monopolist would maximize profit by equatimg marginal cost with inarginal revenue, $M R$, setting price equal to $P_{2}$ and quantity equal to $Q_{2}$. As Figure 1 is drawn, $P_{2}$ is exactly twice $P_{0}$. The profit of the price-maximizing monopolist is the trapezoid with corners at points a, g, h, and $i$. These profits are sigunficantly greater than the profits the firm would reap if it charged the competitive price.

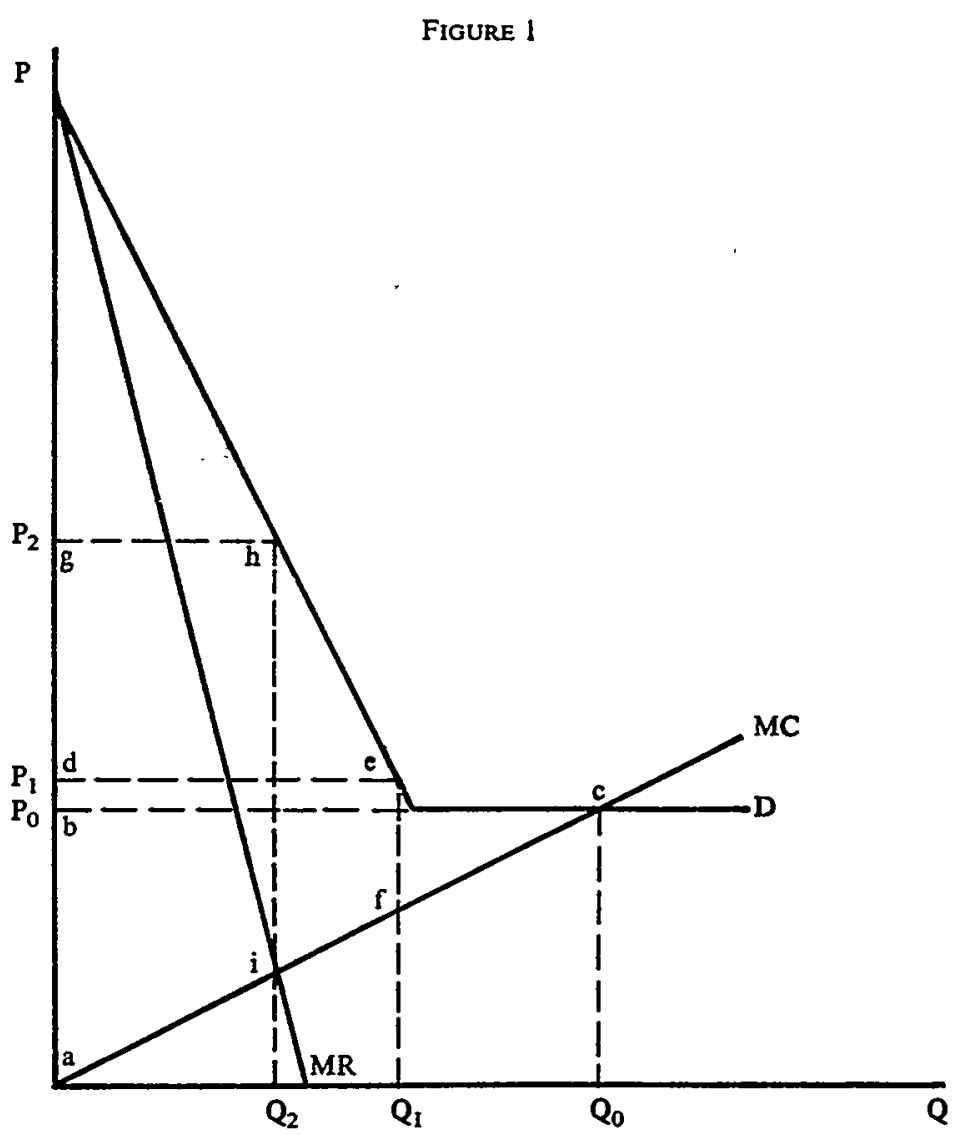

95. See infra note 129 and accompanying text (providing an example of such a price increase). 
a price increase can be significant even though it is sunall. Although it is reasonable to note that sinall increases may be significant, the Guidelines' use of the word "small" in the definition of a inarket is inappropriate and misleading. Thus, the significance test should be based on the inost profitable price increase, not a sinall price increase or the largest price increase that would produce an increase in profits. It is assumed throughout this article that this is what the Guidelines intended.

\section{Defining a "Significant and Non-Transitory Increase in Price."}

Given the Guidelines' definition of a market, 96 the choice of quantitative thresholds for what is a "significant and non-transitory increase in price"97 is very important. It is also clear that any threshold must be arbitrary. The Guidelines do not adopt any particular standard as a hard-and-fast rule, but indicate that the Department will use as "a first' approximation" a price increase of five percent for one year.98 The Guidelines also note: "Judged by the effect on rate of return on imvested capital, a given percentage price increase may be much inore significant in some industries than others." 99 The inherent arbitrariness of price and time thresholds inakes it impossible to conclude either that the Guidelines' use of five percent and one year is correct or that it is incorrect. It is possible, however, to analyze the various considerations that are relevant to the choice of price and time thresholds and to examine critically the Guidelines' suggestion that thresholds should vary according to the rate of return on investment that a price increase. would cause.

Among the factors important in choosing thresholds for a "significant and non-transitory increase in price" are the three discussed in the context of determining price. First, if collusion would cause only a very small or very brief price increase, it is unlikely that the benefits of collusion would exceed the costs. ${ }^{100}$ In weighing the costs and benefits of collusion, firms look to the total dollar profits that collusion would generate. Second, even if the possibility of a very small or very brief price increase would induce firms to collude, it still imght not warrant governmental intervention in the marketplace because it might not significantly reduce economic welfare. ${ }^{101}$ The effect on economic welfare of a particular increase in the price of a particular product depends on

96. See supra text accompanying note 36 .

97. Id

98. 2 TRADE REg. REP. (CCH) If 4502.10, 4502.30 .

99. Id If 4502.10 n.10, 4502.30 n.22.

100. See supra notes $73-74$ and accompanying text.

101. See supra notes $75-76$ and accompanying text. 
many things but is closely related to the amount of the mcrease it induces in the prices of final goods and the total amount of income consumers spend on those goods. Third, subject to exceptions, the Guidelines follow the principle of choosing the smallest relevant market in which a hypothetical present and future monopohst would significantly increase price. ${ }^{102}$ Thus, the use of very low price and time thresholds could produce relevant inarkets too small to be useful analytical tools.

Several additional factors are also relevant in selecting particular thresholds. First, a hypothetical nonopolist generally would increase price more, possibly much inore, than would any likely cartel. Market delineation under the Guidelines is predicated on the price effects of perfect collusion, but collusion is rarely perfect. Price fixing is illegal in the United States, and although the legal prohibition is not sufficient to prevent all collusion, it does discourage explicit written agreements and various other devices generally necessary to perfect collusion. Under these circumstances, coordinating the price and output decisions of several firms is difficult; it is likely that soine firms nominally part of a cartel would be able to cheat without detection. ${ }^{103}$ Thus, cartels that do form are likely to be highly imperfect. It is not possible to measure the extent of cartel imperfection, but it is likely to be substantial and should have a substantial effect on the choice of a price threshold for market delineation. Whether collusion would be profitable or would significantly lessen econormic welfare depends on the price increase collusion would actually produce, not that resulting from perfect collusion.

Uncertainty also plays a role in setting price and time thresholds. There are two quite different issues related to different types of uncertainty. One type is the uncertainty that buyers have about the interpretation of a price increase and the availability of substitutes. When one sees a higher gasoline price at the corner station, there may be no way to know whether some other nearby station might have inaintamed a lower price. When a manufacturer sees a higher price for a raw material, he cannot know whether the price increase will persist or whether the prices of other materials also will rise. How unuch one will invest in searching for a lower gasoline price depends on what one expects to

102. See supra notes $64-68,77-78$ and accompanying text.

103. For a useful discussion of the problem of detecting collusion, see Stigler, $A$ Theory of Oligopoly, 72 J. Pol. EcoN. 44 (1964). 
find. 104 Whether and to what extent a manufacturer will adjust his production process depends on his perceptions of likely future prices of various materials. The more uncertainty there is, the less substitution a price increase will be likely to induce. In choosing particular price and time thresholds, the Guidelines simplify matters by assuming "that buyers and sellers immediately recognize the price increase and believe it will be sustained for the forseeable future." 105 Thus, the Guidelines assume away some, if not all, of the uncertamty on the part of buyers that could limit substitution. ${ }^{106}$ As a result, analysis under the Guidelines will understate somewhat the extent to which a hypothetical inonopolist actually would imcrease price, and that fact should be considered in the selection of price and time thresholds for market delineation in a particular case.

The Guidelines do not mention the other type of uncertainty relevant to the choice of thresholds-uncertainty with respect to the amount by which a hypothetical monopolist would increase price. Needless to say, precise measurement is generally impossible. Given the existence of this uncertainty, the amount by which a hypothetical monopolist would choose to raise price can be expressed either as a "probability density," a series of price increases with associated probabilities, or as a "point estimate," a single, best-guess estimate of the price increase. A point estimate is simpler and is most likely to be used, but great care inust be exercised in assessing whether the applicable price imcrease threshold is met. Suppose an applicable threshold of five percent and a best-guess estimate of the amount by which a hypothetical monopolist over a particular product in a particular area would. increase price also of five percent. The threshold probably should not be deemed met because it is probably just as likely that price could not be raised five percent as that it could. Indeed, there may be a signifi-

104. For a formal statement of the search problem and the optimal response to it, see Rothschild, Searching for the Lowest Price When the Distribution of Prices is Unknown, 82 J. Pol. EcoN. 689 (1974).

105. 2 Trade Reg. Rep. (CCH) T 4502.10 n. $10,4502.30$ n.22.

106. The extent to which the Guidelines mean to assume away buyers' uncertainty about alternatives is unclear. If they do mean to assume away this type of uncertainty totally, the assumption may be unfortunate. The presence of this type of uncertainty can be a powerful force in creating market power. If consumers have very pocr information about the prices of alternative products or of the same product sold in other areas, it will be much more profitable for sellers to increase price. See generally Rothschild, supra note 104. A hypothetical monopolist of a particular product in a particular area might find a price increase of five percent for one year to be profitable ouly because buyers would not readily discern the fact that acceptable substitutes are available. In sach a case, the product and area should be considered to be a market (assuming the price and time thresholds to be reasonable), but they would not be considered a market if, as the Guidelines seem to require, such uncertainty were assumed away. 
cant probability that price would not be increased as much as one percent. ${ }^{107}$ Clearly, the extent of uncertainty about the estimated amount by which a hypothetical monopohst would increase price should play some role in determining the appropriate price increase threshold or in determining whether it is met.

In sum, six factors must be taken into account in selecting price increase and duration thresholds for market delineation. With the exception of the buyers' uncertainty assumed away by the Guidelines, each of these factors imphes that very small or very brief price increases should not be considered significant. None of the factors provide any firm basis for quantifying significance, and each of the factors has somewhat different implications. Thus, relatively little can be said about the appropriateness of the Guidelines' "first approximation" thresholds of five percent and one year.

Nevertheless, one may still consider whether and how the thresholds should vary from one case to the next. The Guidelines suggest that the thresholds should vary according to how a price increase of a given magnitude translates into an increase im the rate of return on imvestment, but they do not indicate why this rate of return should be determinative or even whether the Department intends to base its analysis on rates of return on investment. ${ }^{108}$ The six factors that govern the clioice of price and time thresholds suggest that thresholds might properly be varied according to the dollar volume of commerce and according to the degree of estimation uncertainty, but not according to the effect of a price increase on rate of return on investment.

From the perspective of economic welfare, the dollar volume of commerce is extremely important. It is possible for a one percent increase in price to produce a substantial reduction in economic welfare in a market that is very important to the econony. Other things being equal, increasing the dollar volume of commerce in a market may also imcrease the likelihood of collusion because the benefits would rise more than the costs. Despite these arguments, it probably would be undesirable to vary price and time thresholds explicitly according to the dollar volume of commerce involved. It is not possible to develop a simple, sensible rule for adjusting the thresholds as the volume of commerce varies. There is no simple relationship between the volume of commerce and the likelihood of collusion, and the welfare effects of a

107. The estimate of the amount by which a monopolist would increase price is merely that. While the best-guess estimate is five percent, the true value may be much larger or inuch smaller. Depending on the degree of uncertainty, there may be a significant probability that the true value is as low as one percent or as high as ten percent.

108. 2 TRADE REG. REP. (CCH) $\uparrow \uparrow 4502.10$ n.10, 4502.30 n.22. 
price increase can vary considerably even if the dollar volume of coinmerce is fixed. Even if a simple rule could be found, its application probably would be inappropriate where it suggested very low thresholds. Other factors, such as the market size implications of thresholds and the inherent uncertainty of price increase estimates, militate against the use of very low thresholds in any case. Although the dollar volume of commerce is a relevant consideration for an enforcement agency deciding whether to devote substantial resources to a case, it probably should not be considered in market delineation.

A better case might be made for explicitly varying price and time thresholds according to the degree of uncertainty in the estimates of the price effects of a hypothetical monopolist. This too, however, would be highly complicated and probably not worth the effort. Uncertainty can and should be taken into account, but this is probably not best done by: adjusting the numerical price and time thresholds on a case-by-case basis. Either of two alternatives would be much simpler. First, if bestguess estimates of the amount by which a monopolist would increase price are used, the thresholds could be adjusted upward to guard against the possibility that the best-guess estimates would exceed the threshold despite a substantial likelihood that price would not be increased nearly that much. Second, if probability densities are used, one could insist on having a reasonable degree of confidence that the threshold actually is exceeded. For example, if the price increase threshold were five percent, one could require that there be at least a seventy-five percent probability that a monopolist would raise price by at least five percent. ${ }^{109}$

The Guidelines' suggestion that price and time thresholds should vary according to the effect of a particular price increase on rate of return on investment warrants reconsideration. The Guidelines' suggestion clearly is not attributable to considerations of economic welfare, inarket size, imperfect collusion, or uncertaimty. Although the rate of return on investment might be linked to the likelihood of collu-

109. It is well established that "[d]etermination of the relevant product and geographic markets is a 'necessary predicate' to deciding whether a merger contravenes the Clayton Act." United States v. Marine Bancorporation, Inc., 418 U.S. 602, 618 (1974) (citations omitted). It is also clear the plaintiff has the burden of "proving" a market in a section 7 civil action. See, e.g., J. voN KAIINOWSK1, supra note 3, \& 18.01[1]. It is unclear exactly what the plaintiff must do to meet this burden. Certainty is impossible and clearly is not required. See, èg., Umited States v. Connecticut Nat'l Bank, 418 U.S. 656, 669 (1974); United States v. Philadelphia Nat'l Bank, 374 U.S. 321, 360 n.37 (1963). The Supreme Court has characterized plaintiff's burden as simply "to come forward with evidence delineating [a] rough approximation" of the relevant markets. Connecticut Nat'] Bank, 418 U.S. at 669-70. This suggests that the degree of certainty required is not great. Whether a seventy-five percent probability is the proper standard is impossible to say, but it seems consistent with the case law. 
sion, it is difficult to see why collusion is more likely when a five percent price increase for one year would produce a doubling in the rate of return than when the same price increase would cause rate of return to imcrease by only one-quarter. The effect on total dollar profits may be the same in the two cases, and this is what should be important in the competitors' weighing of the benefits and costs of collusion. In delineating markets, price and time thresholds for significance should not vary according to the effect of a particular price increase on rate of return on investment. ${ }^{110}$ Thus, it is probably best to use the same basic price and time thresholds for market delineation in all cases.

Any decision about particular thresholds must be based finally on intuition. The Guidelines' choices of five percent and one year defimitely seem to be im the right neighborhood, but may be a bit on the low side, particularly with respect to time. If a five or even ten percent price increase could be sustained for only one year, it seems unlikely that it would be imposed in the first instance. Customers who switched to other products or to the same product produced in other areas might not return if price were lowered again after a year. Even if this prospect would not dissuade a hypothetical monopolist from raising price, potential cartel participants might be dissuaded because they could experience a permanent loss of customers to sellers that did not participate in the cartel and to those that participated nominally but cheated. Moreover, if there are any long-run economic benefits froin a merger, they can easily outweigh the costs to society of a one-year price increase. ${ }^{111}$ Using a time period of two or three years would lessen both of these problems substantially. On the other hand, increasing the time

110. The Guidelines use the same five percent threshold (but a different time threshold) in assessing the ease of supply substitution and de novo entry as well as in delineating markets. See 2 TRADE REG. REP. (CCH) ๆI 4502.10, 4502.30, 4503.20. Rate of return on investment clearly is relevant in selecting a threshold for evaluating the ease of de novo entry. A firm deciding whether to enter a market will compare the expected rate of return and risk with those of alternative investments. For any given level of risk, a higher rate of return on investunent will attract more entry because, for a greater number of firms, this particular market would be the most attractive available investment. A similar argument can be made for firms that could produce the product in question with existing facilities but are not currently doing so. Thus, the Guidelines' references to the effect of a price increase on rate of return probably were inotivated by considerations of entry and supply substitution, even though they are contained in the Guidelines' sections on inarket delineation. See id. II 4502.10 n.10, 4502.30 n.22.

111. The balance of costs and benefits of a merger through time depends critically on the rate at which future costs and benefits are discounted back to the present. Using a discount rate of five percent (in real terms, net of inflation), a permanent one percent reduction in costs would balance out a one year price increase (for the same volume of commerce) of 20.5 percent. Such a cost reduction would balance out a three year price increase of 7.2 percent. With a discount rate of ten percent, the price increase figures would be about 10.5 percent and 3.9 percent respectively. In either case, fairly inodest cost savings could outweigh a one year price increase of well over five percent. 
threshold from one year to two or three frequently would make little difference. If consumer substitution to other products or areas would be sufficient to deter a five percent price increase for three years, it probably also would be sufficient to deter a five percent price increase for one year. ${ }^{112}$

The propriety of the five percent price increase threshold is less clear. Most of the factors that govern the choice of a standard offer no definite basis for preferring five percent over two percent or ten percent. Two factors, however, do suggest that the threshold should be higher than five percent. A five percent standard combined with the Guidelines' principle of choosing the smallest market makes it fairly likely that relevant markets will be delineated too narrowly. If merging firms nevertheless were considered to be in the same market, concentration and shares would tend to be exaggerated. If inerging firms were not considered to be im the same market, meaningful competition could be ignored. In either event, the relevant market delineated under the five percent standard would be a poor tool for analysis. These problems would be particularly acute if price were measured anywhere but at the point of final consumption. ${ }^{113}$

An increase in the threshold to ten percent would minimize this potential problem and would also mitigate the problem of uncertaimty. ${ }^{114}$ Uncertainty in estimates of the extent to which a hypothetical monopolist would raise price generally will be of sufficient magintude that if, for example, the best-guess estimate were five percent, there would be a significant probability that price would not be raised even two percent. Under such circumstances, it probably would be best that

112. In general, the amount of substitution that a particular price increase would induce increases continuously as the time period under consideration increases. However, for inany products, particularly certain consumer goods, the great bulk of the substitution that would eventually take place would occur fairly quickly. Indeed, a price increase might even induce a temporary backlash by consumers who wish to express their resentunent through the best available ineansreducing their purchases. For other products, particularly producer gopds used in conjunction with long-lived capital goods, substitution could be very slow indeed, with the full extent of the substitution possibly taking several decades. In either case, it would make little diffcrence whether the time threshold were one year or ten years. Cases in which a substantial proportion of the total substitution would occur after one year but in less than three years are certainly possible but probably are not very common.

Note also that the one-year time period in the Guidelines may be equivalent to two or three years of actual time. The Guidelines assume away recognition lags on the part of buyers. See supra notes 104-06 and accompanying text. In the real world, it might take more than a year before a price increase was fully recognized and buyers began to substitute. Thus, even if substitution would occur within one year as far as the Guidelines were concerned, it might really take much longer than a year.

113. See supra notes $90-91$ and accompanying text.

114. See supra notes $104-07$ and accompanying text. 
the area and group of products at issue not be considered a market. Raising the threshold to ten percent would greatly reduce this problem. Alternatively, one could abandon reliance on best-guess estimates and insist that there be, for example, at least a seventy-five percent probability that the price increase would exceed the five percent threshold. The former approach is simpler, and some combination of the two may be best.

Increasing the thresilold to ten percent would not risk significant costs to society by permitting inergers that would decrease economic welfare. If a hypothetical monopolist would not increase price ten pericent, an imperfect cartel probably would not increase price five percent. Moreover, the prospect of a five percent price increase often would not be sufficient to induce firms to incur the costs of collusion or to produce a significant reduction in economic welfare if they did collude. In practice, however, the difference between a five and a ten percent threshold often will be insignificant. In particular, this will be the case if natural market boundaries exist and are used to delineate the relevant market. In such cases the price increase that would result from inerging all present and future sellers together generally will exceed ten percent.

In conclusion, although the Guidelines' use of a five percent price increase for one year as "a first approximation" of the significance thresholds for delineating markets seems fairly reasonable, the thresholds may be a little too low. Intuition suggests that increasing the thresholds to ten percent and two or three years would reduce the likelihood that markets will be too narrowly delineated. The higher thresholds would not significantly increase the risk of permitting mergers that create or enhance market power. In many cases, however, the use of higher thresholds probably would not produce a significantly different result. If natural market boundaries are emphasized, the choice of particular thresholds becomes unuch less important. There should be no systematic variation in the price and time thresholds from one case to the next, but some consideration probably should be given to the degree of certainty in the estimates of the extent to which a hypothetical monopolist would increase price.

\section{E. Interrelations beiween the Product and Geographic Dimensions of Markets.}

The Guidelines define a market as an area and group of products that ineet certain conditions. In the definition, the product and geographic dimensions of markets are determined together; however, the Guidelines also are frained in terms of delineating separately "product 
markets" and "geographic markets,"115 - the traditional approach to the problem of market delineation. Although this practice simplifies matters, it has certain pitfalls that can be avoided by keeping the Guidelines' basic principles of market delineation firmly in mind.

The procedure described by the Guidelines is first to delineate a "product market" and then to delineate a "geographic market" for that product. In delineating a "product market," the Guidelines ignore any geographic substitution that might occur and ask whether a present and future monopolist would impose "a significant and non-transitory increase in price."116 "As a first approximation," the Guidelines "hypothesize a price increase of five percent ... [for] one year." 117 The Guidelines outline a similar procedure for delineating the "geographic market." In addressing this issue, the Guidelines "assum[e] that buyers could respond to a price increase within a tentatively identified area only by shifting to firms located outside the area." 118 The Guidelines ask whether a "significant and non-transitory increase in price" would be profitable, again using, as "a first approximation," "a price increase of five percent . . . [for] one year." 119 This description of the inarket delineation process seems to mdicate that substitution to other products is ignored in delineating a "geographic market"; however, such a procedure would be incorrect.

If product substitution were totally ignored in delineating "geographic markets," there would be no assurance that the resulting geographic area and group of products would satisfy the Guidelines' definition of a market. If, in delineating a "geographic market," a five percent threshold were barely met while ignoring product substitution, it would not be met if product substitution were considered. ${ }^{120} \mathrm{Al}-$ though first considering product and geographic substitution in isolation generally poses no problems, at some point the two must be considered together. This consideration need not always be extensive. If the substitution that a price increase would induce were primarily to the saine product produced in other areas, little attention would have to be paid to product substitution. Ignoring product substitution alto-

115. See 2 TRADE REG. ReP. (CCH) \$ 4502.10, 4502.30.

116. Id. I 4502 n.6.

117. Id. 4502.10 .

118. Id. 4502.30 .

119. Id.

120. If product and geographic substitution wcre considered separately and a particular area and group of products barely inet the applicable price increase threshold in both cases, the area and group of products would not meet the threshold together and should not be considered to be a market. Generally, the most profitable price increase for the area and group of products would fall well short of the threshold, typically by nearly half. 
gether would only slightly distort the analysis of the geographic dimensions of markets in such cases.

The product dimensions of the market may differ significantly depending on location. This may occur for any number of reasons. For consumer goods, there may be substantial regional differences in tastes. For producer goods, there may be significant differences in important legal restrictions such as environmental laws. For all kinds of products, the relative prices of substitutes may differ dramatically from one area to the next. Thus, geography cannot be ignored completely in delineating the product dimensions of markets. One can consider product substitution apart from geographic substitution, but product substitution must be evaluated in the context of the economic environment of the relevant region.

Furthermore, the scope of a market in product space is related to its scope in geographic space. To be deemed a market under the Guidelines, an area and group of products must be such that a hypothetical present and future inonopolist would imcrease price significantly. Standing alone, the Guidelines' definition of a market would allow one to trade off the product and geographic dimensions of markets. That is, one could delineate a market consisting of a relatively narrow group of products and a relatively broad area, or of a relatively broad group of products and a relatively narrow area. Either would satisfy the Guidelines' definition. However, the Guidelines also contain a principle that markets must, in some sense, be circular, ${ }^{121}$ and this primciple prohibits making such explicit tradeoffs. What it means for markets to have the same radius in product space as in geographic space is not well defined. Nevertheless, if the first area and group of products considered is too narrow to satisfy the Guidelines' definition, it is important that products and geographic areas be added based on the extent of the substitution between them and those already included. If a hypothetical present and future monopolist would not increase price sufficiently to warrant considering the initial area and group of products a market, one inust determine whether the substitution that would undercut the profitability of a price increase would be primarily product or geographic substitution and expand accordingly.

In short, although the Guidelines are phrased in terms of the separate delineation of product markets and geographic markets, there is no such thing as a "product market" or a "geographic market" under the Guidelines' definition of a market. The product and geographic

121. See supra notes $51-56$ and accompanying text. 
dimensions of markets are closely related and cannot be considered in isolation.

\section{Applying the Guidelines' Market Delineation Principles}

Application of the Guidelines' fairly abstract principles of market delineation is best illustrated by considering an example and several variants. This example demonstrates low the principles would work if there were no inforination problems. It clarifies many of the Guidelines' market delineation principles and illustrates the conditions under which a significant price mcrease would be imposed by a present and future monopolist. The Guidelines' definition of a market; however, poses questions that cannot be answered with certainty and precision because answering them requires infornation that simply is not available. This section briefly considers the evidence that can be mustered in delineating markets and the tools for interpreting it. In some cases, detailed evidence and sophisticated tools can and should be used, but more often, the best evidence is impressions and intuition.

\section{A. Application of the Guidelines' Market Delineation Principles: An Example.}

To simplify matters, the following example assumes a hoinogeneous product with no good substitutes, so that the product dimensions of the market are absolutely clear and the only issue is determining its geographic dimensions. It is assumed also that both buyers and sellers are contimuously and uniformly distributed throughout a limitless plane, that the product is sold f.o.b. the factory gate, and that transportation cost is uniform per air mile. With this distribution of buyers and sellers, there is one buyer and one seller at every point in the plane. Because there are no gaps in the distribution of buyers or sellers and transportation cost is uniforn, there can be no natural market boundaries. Thus, the size and shape of the relevant market must be determined solely by the principles used to delineate it.

Under the Guidelines, the procedure focuses on the locations of the plants of the inerging firms and considers a series of circles ${ }^{122}$ of increasing size around each such plant. For each circle, one determines the extent to which a hypothetical present and future inonopolist would increase price, or at least whether that price increase would exceed the applicable thresholds. This is determined by the extent of product and gcographic substitution by consumers as price increases. For simplicity, it is assumed that any substitution that would occur as price in-

122. See supra notes $51-56$ and accompanying text. 
creases would be immediate. Thus, the only issue is the amount of the price increase, which would be permanent.

To permit calculation of the amount by which a profit-maximizing monopolist would increase price, it is necessary to posit particular demand and cost conditions. It is assumed that there is a constant marginal production cost with no fixed costs and no capacity constraints and that the demands of consumers in each unit of area are a linear function of price with a slope of negative one and with quantity demanded falling to zero as price rises to twice unit production costs. ${ }^{123}$ Consumers are assuined to make no distinction between the products of various sellers and to purchase from the seller witl the lowest delivered price. If all sellers charged the same price, the seller with the lowest delivered price for eacli buyer would be located at exactly the same point as that buyer, and no transportation costs would be incurred. If sellers in a circular area elevated their prices above those of their neighbors, consumers just inside that circle would begin buying from sellers outside the area. The group of custonners that would continue to purchase from sellers in the circle also would be bounded by a circle. Its radius would be less than that of the sellers' circle by an amount determined by the price increase and the transportation costs. Transportation is assuned to be available in unlimited quantity at a price equal to one-thousandth of the umit production cost of the product per mile. ${ }^{124}$

Table 1 below shows the percentage price increase that would be imposed by a profit-1naximizing nnonopolist in circular areas of various radii.

123. Mathematically, quantity demanded per unit of area as a function of price is $2 c-p$, where $p$ is price and $c$ is average unit cost of production. Because the value of $c$ does not affect the percentage increase in price that would be imposed by a monopolist, it can be taken to equal one as a matter of convenience.

124. This transportation cost figure is roughly an order of magnitude greater than the average transportation cost for actual manufactured products. See F. SCHERER, A. BECKENSTEIN, E. KaUfer, \& R. MURPhy, The Economics of Multi-Plant Operation 429-33 (1975). Thus, the discussion below suggests, but does no more than suggest, that the geographic dimensions of markets for most manufactured commodities are large (at least national in scope). See infra notes 125-29 and accompanying text. 
TABLE 1

\begin{tabular}{cccc}
\hline $\begin{array}{c}\text { Radius in } \\
\text { Miles }\end{array}$ & $\begin{array}{c}\text { Percentage } \\
\text { Price } \\
\text { Increase }\end{array}$ & $\begin{array}{c}\text { Percentage } \\
\text { of Sales } \\
\text { Area Lost }\end{array}$ & $\begin{array}{c}\text { Percentage } \\
\text { of Sales } \\
\text { Lost }\end{array}$ \\
\hline 25 & .8 & 55.3 & 55.7 \\
50 & 1.6 & 55.1 & 55.8 \\
75 & 2.5 & 54.8 & 55.9 \\
100 & 3.3 & 54.5 & 56.0 \\
150 & 4.8 & 54.0 & 56.2 \\
155.6 & 5.0 & 54.0 & 56.3 \\
200 & 6.4 & 53.5 & 56.4 \\
300 & 9.3 & 52.4 & 56.8 \\
325.0 & 10.0 & 52.1 & 56.9 \\
400 & 12.1 & 51.2 & 57.1 \\
500 & 14.6 & 50.0 & 57.3 \\
514.3 & 15.0 & 49.8 & 57.4 \\
600 & 17.1 & 48.8 & 57.5 \\
700 & 19.3 & 47.5 & 57.6 \\
733.3 & 20.0 & 47.1 & 57.7 \\
800 & 21.4 & 46.3 & 57.7 \\
900 & 23.3 & 45.0 & 57.8 \\
1000 & 25.0 & 43.8 & 57.8 \\
1500 & 31.7 & 37.8 & 57.5 \\
2000 & 36.0 & 32.7 & 56.9 \\
3000 & 40.7 & 25.3 & 55.7 \\
5000 & 44.6 & 17.0 & 54.0 \\
$\infty$ & 50.0 & 0 & 50.0 \\
\hline
\end{tabular}

It is assumed that the initial price is the competitive price, which equals the marginal cost of production, and that sellers other than the hypothetical monopolist continue to price competitively. The table demonstrates that the amount by which price would be increased rises continuously with the size of the area monopolized, approaching its maximum only as the size of the area approaches infinity. As the size . of the area monopolized approaches infinity, geographic competition becomes nil, and only product substitution constrams price. Under the demand conditions posited, a monopolist of the product throughout the entire plane would increase price by fifty percent.

The most obvious lesson to learn from this example is that the choice of a significance threshold can make a tremendous difference. Applying the Guidelines' five percent "first approximation," the product in question combined with any area with a radius of at least 155.6 miles would be deemed a market. Applying the Guidelines' principle of choosing the smallest market, the relevant market for each plant of either merging firm would have a 155.6 mile radius around the plant. By contrast, if a ten percent threshold were used, the relevant market would have a radius of 325.0 miles, and an area 4.4 times that of the 
relevant market under the five percent standard. Use of standards of 15,20 , and 25 percent would produce relevant markets with radii of $514.3,733.3$, and 1000.0 miles, and areas equal to $10.9,22.2$, and 41.2 times the area under the five percent standard. If transportation costs per mile were changed, the radii that produce any particular price increases would change, but the relative sizes of the relevant markets that would result from particular price thresholds would not. For example, using a transportation cost one-tenth of that assumed above would simply cause all the figures in the first column of the table to mcrease by a factor of ten.

Now consider the effect of introducing natural market boundaries. ${ }^{125}$ If it were assumed that buyers and sellers were distributed throughout a circle with a finite radius centered on one of the merging firms, rather than throughout an infinite plane, there could be a dramatic jump in the amount by which a monopolist would increase price at a radius equal to that of the circle. For example, if the entire universe in the example were only 300 miles in radius, a monopohist over a 200 -mile radius would still increase price 6.4 percent, but a monopolist over the entire 300 miles would increase price fifty percent, as would a monopolist over the entire infinite plane.

If the assumption of an infinite plane were maintained while gaps in the distribution of buyers and sellers were introduced, there could be similar but less dramatic results. For example, if there were no buyers or sellers at radii between 300 and 500 miles, a monopolist over a 300mile radius would increase price by twenty percent, whereas a monopolist over a 200 -mile radius still would increase price by 6.4 percent. Given this 200-mile gap in buyers and sellers, a monopolist over 300 miles would be able to increase price twenty percent without losing a single customer to outside sellers, and that would be the most profitable strategy. In a case such as this, it seems clear that the relevant market should have a 300 -mile radius. It would be even clearer if the gap in buyers and sellers were as much as 500 miles, because in that case outside sellers would have no influence at all on the pricing of a monopolist in the insulated center circle. The highest price increase that would ever be desired is fifty percent, and with a 500-mile gap, price could be increased fifty percent without losing any customers to outside sellers. On the other hand, a gap inuch smaller than 200 miles might

125. The importance of natural market boundaries is exaggerated in this example because it was assumed that both transportation services and the relevant product were available in unlimited quantities at a constant price. If there were capacity constraints or if an increase in price would be necessary to induce sellers to increase output, as is likely in the real world, the importance of natural market boundaries would be reduced. 
have little effect on pricing. If there were a fifty-mile gap beyond the 300 -mile radius, a monopolist in the 300 -mile radius would increase price 10.7 percent, while the price imcrease would be 9.3 percent if there were no gap.

The relative importance of geographic and product substitution in this example depends on the assumptions made. However, the example does demonstrate the imtuitive result that, in determining the geographic dimensions of markets, product substitution can be ignored fairly safely if demand for the product is relatively inelastic. In the relevant range of prices in this example, the elasticity of product demand is between negative one and negative three. ${ }^{126}$ This is significantly different from zero, yet, im markets with relatively small geographic radii, the amount by which a monpolist would increase price would rise only slightly if product demand was assumed to be totally melastic. In a 200 -mile radius, a monpolist would increase price 6.7 percent rather than 6.4 percent; and in a 400 -mile radius, the price increase would be 13.3 percent rather than 12.1 percent. This does not show that it is always safe to ignore product substitution in delineatimg. the geographic dimensions of markets. The example does illustrate, however, that there is little danger in ignoring product substitution if, as here, the geographic elasticity of demand is much greater (in absolute terms) than the product elasticity of deinand.

Another notable feature of this example is the amount by which the maximum price increase that would produce a net increase in profit exceeds the most profitable price increase. ${ }^{127}$ The example assumes that cost per umit of output is constant and that the initial price is the competitive price, which is the marginal cost of production. Under these conditions, firms earn no economic profit. ${ }^{128}$ Any higher price at which consumers would purchase some of the product would generate some economic profit. Thus, the maximum price increase that produces a net increase in profit is just less than the price imcrease that reduces quantity demanded to zero. In any market with a radius of under one thousand miles, the price at which quantity demanded becomes zero is the price that is just high enough to permit sellers outside the market to undercut those inside evcn at the center of the circle, where the outside sellers' disadvantage is greatest. This price is easily

126. Elasticity of demand at any point on the demand function is its slope, times price, divided by quantity. The example above assumed that the slope of the deinand function was negative one, and that price divided by quantity was one at the competitive price and three at the monopoly price.

127. See supra text accompanying note 93.

128. Firms do earn a normal return on investment, but in economic terms this is considered part of cost rather than profit. 
calculated. The example assumes transportation cost to be one-thousandth of unit production cost per mile. Thus, for a thousand-mile circle, the delivered price of a seller located just outside the circle would equal that of the seller at the center of the circle if all sellers in the circle raised price one hundred percent. Similarly, for any lesser radius, the maximum profitable price increase in percentage terms is the radius in miles divided by ten. Thus, the maximum profitable price increase is three or more times the most profitable price imcrease.

The example also well illustrates two other important points. The first is that firms need not be direct competitors to be in the same market. There are two reasons for this. First, the relevant competition is with the merging firm that occupies the center of the circle. In many cases, the distance, in geographic space or in other dimensions, between two sellers in a market will be greater than the distance between the firm in the center and any other firm. Second, the outermost firms in a market generally will not compete directly with the firm in the center. Both in the example and in many real-world situations, there are many sellers between the center and the edge of a market. Each seller may compete directly only against surrounding sellers, but the indirect coinpetition with more distant sellers generally will be sufficient to ensure that a firm and its immediate competitors would not, if merged, significantly increase price.

Additionally, it should be observed that markets can be relatively small in geographic space even if the total transportation cost incurred is slight. At the initial competitive price in the example, no transportation costs are imcurred even though the market is fairly small. The amount of transportation cost incurred depends on many things, most notably the proximity of sellers to their customers. In the example, the two were at the same point. In the real world, any number of factors make such a location pattern uneconomical and cause transportation costs to be incurred; however, those factors may or may not signifcantly affect market boundaries.

Finally, the example illustrates the extent to which a monopolist will restrict output. The last column in Table 1 above demonstrates that the total restriction in output that a profit-maximizing monopolist will impose, compared with the competitive output, is approximately fifty percent. This is the case regardless of the radius subject to the monopoly. Moreover, a similar result would have been obtained for many demand functions other than the function used in the example, 
provided that the marginal cost of production was roughly constant. ${ }^{129}$ Thus, for industries with roughly constant marginal production costs, it is reasonable to conclude that a product and area constitute a market if a five or ten percent price increase by a hypothetical monopolist would be likely to cause significantly less than a fifty percent reduction in the quantity it sold. It is more difficult to develop a similar rule of thumb for industries with marginal production costs that increase with output. In such cases, the competitive price will equal the marginal cost of production, as it does with constant costs, but at this price sellers will earn an economic profit on the infra-marginal units. Some of this profit would have to be sacrificed if output were restricted, and therefore the most profitable output restriction would be less than is the case when unit production costs are constant. Depending on the rate at which unit cost rose with increased output, the optimal output restriction could be nearly fifty percent or virtually nil.

The discussion thus far has been confined to the special and unrealistic case in which there is a continuous and uniform distribution of both buyers and sellers. A similar analysis could be performed under any other set of assumptions. There is no need to engage in a detailed analysis of other examples; however, it is worthwhile to make a few general points about how such cases can be analyzed and about how the results differ from those in the case analyzed above. If both buyers and sellers were uniformly distributed, but only the distribution of buyers were continuous, a monopoly of any particular size would imcrease price by a lesser amount than it would if sellers were also continuously distributed, all other things being equal. If sellers were not continuously distributed, increasing price would cause the area in which the monopohist is the low-dehivered-price seller to shrink faster than it would with a continuous distribution of sellers.

Figure 2 below illustrates the point. At the center is one of the merging firms, and surrounding it are six competitors, each of which is the same distance from the inerging firm. Each of those firms also is surrounded by six equally distant competitors. If the inerging firm and its six direct competitors priced competitively, they would supply customers within the outer boundary of the figure (indicated by the heavy,

129. If marginal production cost is precisely constant and demand is linear, a monopolist will produce exactly half of the quantity that a competitive market would produce. Many nonlinear demand functions produce a very similar result. In the example, demand is not linear despite the assumption that product demand is linear. The relevant demand function is the function for the product and area under consideration, and, in the example, geographic substitution is such that the demand function is not linear. On the other hand, a monopolist over the entire infinite plane would not experience any geographic substitution as it raised price; therefore, its demand would be linear. Thus, output would be restricted by exactly fifty percent as shown in the table. 


\section{FIGURE 2}



solid line), which consists of the union of the hexagonal areas around each of these seven sellers (the other sides of which are indicated by heavy, dashed lines). This figure can best be thought of as a circle with "dents" in it. An increase in price would cause the area in which one of the seven sellers is the low-delivered-price seller to shrink to the area bounded by the light, solid line. The area does not contract uniformly; it contracts significantly wore at the "dents" between sellers. As drawn, the seven sellers would lose approximately forty-three percent of their total customers. Had their sales area contracted uniformly, maintaining its shape, they would have lost 39.3 percent of their custoiners. More importantly, if sellers were continuously distributed and the figure circular, as in the previous exainple, they would have lost 
only 30.6 percent of their customers. The "dents" in the sales area opposite certain competitors cause quantity sold to decline significantly more than it otherwise would for any given increase in price, and as a result, cause a significantly smaller price increase to be preferred.

Even if buyers and sellers are neither continuously nor uniformly distributed, it is possible to calculate the customer loss that a price increase would produce through geometry similar to that used to produce the figure above. The procedure is simplest in cases in which sellers are located at a few distinct points. First, one must plot the locations of sellers' plants on a map and specify a set of possible geographic boundaries for the market. Next, one inust determine the f.o.b. price at each plant and the appropriate transportation cost between each plant and various points of final consumption. The transportation costs need not be uniform, but uniformity simplifies matters and is assumed in this discussion. One draws a figure based on this information that bounds the customers for whom a seller in the proposed market would have the lowest delivered price. If f.o.b. prices were equal for all sellers, the figure would be a polygon. If the sellers in the proposed market were all at a single point, the polygon would have as many sides as there are points at which sellers just outside the proposed market are located. If, as in Figure 2, sellers in the proposed market were not all at one point, the polygon could have a greater number of sides. In the figure there are twelve sellers just outside the proposed market, but there are eighteen sides to the polygon. Finally, one reconstructs the area in which one of the sellers in the proposed market is the low-delivered-price. seller under the assumption that f.o.b. prices in the proposed market have increased by a certain amount, such as five or ten percent. This second area will be smaller than the first. If the f.o.b. prices of all sellers were the same before the price increase, the prices of sellers in the proposed market would now be higher. That being the case, the figure would no longer be a polygon; rather, its "sides" would be curved back toward the sellers in the proposed market. ${ }^{130}$ Figure 2 exhibits such a pattern. The boundary around customers who would be supplied by the sellers in the proposed market is composed of pieces of eighteen separate curves.

At this juncture, one can compute the extent to which the price increase caused a loss in sales. In the case of uniform customer distribution, the proportion of customers lost through geographic substitution would be equal to the relative difference between the areas of the

130. The curves will be hyperbolae, and the two foci of each hyperbola will be (1) the location of a seller on the periphery of the proposed market and (2) the location of the seller nearest to it hut outside the market. 
two figures constructed. The total loss in customers also includes those lost through product substitution. The same basic procedure could be employed if customers were not uniformly distributed. In that case, it would be necessary to count the number of customers in each figure or to sum their consumption and then compute the loss in sales. The most profitable increase in price could be calculated by repeating this exercise with a number of different price increases and by estimating each time the extent to which costs would fall as quantity sold fell. It would not be necessary to identify the most profitablc price increase, but rather only to determine that it would exceed the relevant threshold. In many cases it would be immediately clear whether the most profitable price increase would exceed the threshold.

Although the delineation of the geographic dimensions of inarkets is conceptually equivalent to the delineation of their product dimensions, the procedure just described is not particularly useful in thinking about product dimensions. In product space, there is no close analogue to transportation cost that governs inarket dimensions. Consumer preferences are often the controlling factors, and they are not easily modeled. Similarly, the foregoing inodels are not particularly helpful in analyzing the geographic dimensions of markets for highly differentiated products subject to distinct consumer preferences. Nevertheless, the models help clarify many of the important concepts in the Guidelines' approach to market delineation and are useful in analyzing certain market delineation issues.

\section{B. Application of the Guidelines' Market Delineation Principles in Practice.}

The discussion thus far has been almost exclusively about the abstract principles of market delineation einbodied in the Guidelines. There rcmains the question of how these principles are to be applied in particular cases. The short answer to that question is that one does what one can. The importance of the Guidelincs' nnarket delineation principles is the conceptual frannework they establish for thinking about the problein. The Guidelines pose a particular question about price increases by a hypothetical monopolist, and they provide certain principles for answering it. However, inarket delineation under the Guidelines poses difficult questions of fact that often cannot be answered objectively and definitely by resort to the available evidence.

Recognizing that direct evidence of the extent to which a monopolist over a product in an area would raise price "often will not be available," the Guidelines indicate that it often will be necessary "to rely on 
inferences from . . . circumstantial evidence."131 The Guidelines also list a number of fairly general "factors" to which "particular weight" will be given. ${ }^{132}$ In evaluating the extent to which a price increase would induce consumers to substitute other products, the Guidelines look to:

(1) Evidence of buyers' perceptions that the products are or are not substitutes, particularly if those buyers have shifted purchases between the products in response to changes in relative price or other competitive variables;

(2) Similarities or differences between the products in customary usage, design, physical composition and other technical characteristics;

(3) Similarities or differences in the price movements of the products over a period of years; and

(4) Evidence of sellers' perceptions that the products are or are not substitutes, particularly if business decisions have been based on those perceptions. ${ }^{133}$

In evaluating the extent to which a price increase would induce consumers to substitute the same product produced in other areas, the Guidelines look to:

(1) Evidence of buyers actually having shifted their purchases among sellers at different geographic locations, especially if the shifts corresponded to changes in relative price or other competitive variables;

(2) Similarities or differences in the price movements of the [relevantl product in different geographic areas over a period of years;

(3) Transportation costs;

(4) Costs of local distribution; and

(5) Excess capacity by firms outside the provisional market. ${ }^{134}$

The Guidelines do not propose specific evidentiary tests, nor do they indicate how one is to evaluate the ultimate issue - the extent to which a monopolist would increase price. Moreover, they do not indicate the relevance of the factors that they list.

The first factor relating to product substitution points to buyers' perceptions about the substitutability of products. Obviously, buyers' perceptions are critical because substitution by buyers is the force that determines market boundaries under the Guidelines, but how is one to identify buyers' perceptions? An obvious possibility is to ask the buyers, and in some cases they may be the best source of information. However, more objective evidence inust be preferred if it is available.

131. 2 Trade Reg. ReP. (CCH) \ 4502.10 n.10.

132. Id. II $4502.10,4502.30$.

133. Id 14502.10 .

134. Id 14502.30 . 
The Guidelines' reference to buyers having actually "shifted purchases ... in response to changes in relative price[s]" suggests that credible, objective evidence in the form of historical patterns of substitution, either anecdotal or econometric, is preferable. But this type of evidence also has important limitations. Anecdotal evidence is always difficult to evaluate, and, though useful, econonnetric evidence must be viewed skeptically because it is based on assumptions that may not be true and often cannot be tested. ${ }^{135}$ Moreover, the precise conditions under which historical substitution has occurred are unlikely to be equivalent to those prevailing now or in the future. If significant changes in the economic environment have occurred, historical evidence may be of hittle or no relevance. In addition, it is particularly hazardous to predict beyond the range of experience. The substitution that occurred when the price of a product rose from ten dollars to twelve dollars may provide no guidance as to what would happen if the price rose from twelve dollars to thirteen dollars.

The Guidelines' second factor for evaluating product substitution consists of objective evidence about the nature and use of the product. Although obviously important, this kind of evidence must be interpreted with great care, particularly in consumer goods industries. Objective criteria may not be the basis for an individual's choice of one product over another, especially if products are highly differentiated. For example, consumers generally do not know the physical similari-. ties and differences between analgesics sold over the counter, and few base their choices on such criteria. Tastes govern the degree of substitutability between one consumer good and another.

Objective criteria are much more useful if producer goods are at issue. Ideally, one can determine the actual cost of substituting one input for another. If this sort of information is available, reliable, quantitative estimates of the extent to which a price increase would induce substitution should be possible because firms can be assumed to minimize cost in their selection of inputs. However, such information

135. Reliable econometric evidence requires that the relevant demand and supply equations be properly specified, that the relevant variables be observed and measured, and that the variables have certain statistical propertics. See generally A. GOLDBERGER, ECONOMETRIC THEORY ch. 7 (1964); H. THeil, PrINCIPLES OF ECONOMETRICs chs. 10-11 (1971). Unfortunately, there is no way to determine the correct specification of the equations; the relevant variables often are unobservable or, at least, not well measured; and the data frequently lack the desired statistical properties. Indeed, there need not be any one correct specification, and the choice of one alternative over another, which must be based on the researcher's personal beliefs, can have a profound effect on the results. See Leamer, Let's Take the Con out of Econometrics, 73 AM. Econ. REv. 31 (1983). Conventional estimation techniques also assume that the observed prices and quantities are equilibrium values; however, that often is not the case. Estimation in disequilibrium situations is even more perilous. 
may not be available. Firms may not know the cost of making a particular substitution because they have never conteinplated doing so. Moreover, even if good information is available on the cost of substitution, the analysis still may be difficult because the relevant substitution .nay not occur at a single point. An increase in the price of a product with inultiple uses inay induce substantially different substitution in the various uses. Even more vexing are situations in which the primary substitution occurs, not at the point at which the product in question is consuined, but rather at the points at which the products inade from it are consumed. Frequently, manufacturers would substitute little if the price of an input increased, at least over the short time horizon postulated by the Guidelines; nevertheless, they would significantly reduce their purchases of the input because the amount of their product that they could sell would fall as the increase in the price of the input was passed through.

Price movements are the Guidelines' third factor for evaluating product substitution. This type of evidence, however, may not be available, and if it is, it can be highly misleading. Economic theory predicts that (in general) the prices of two products that are good substitutes must move together, but it does not predict the converse. The prices of two products inay move together because they both are responding to a third force. The prices of two products made froin petroleum-for example, gasoline and soine type of plastic-would inove together as crude oil prices increase even though the two products are not substitutes at all. Differences between the price movements of two products are much more illuminating. If the prices of two products do not move together, they generally cannot be good substitutes, at least not within the range of observation. 'Products can, however, become good substitutes or ccase to be good substitutes as their relative prices, or other economic factors, change.

The final factor listed by the Guidelines as deserving "particular weight" in assessing product substitution is sellers' perceptions. This type of evidence must be interpreted with the utmost care. Asking the defendants in a merger case, or even their competitors, what products are good substitutes is unlikely to produce useful information. They cannot be expected to give an objective appraisal, and, indeed, they cannot necessarily be expected to know. What the Guidelines envision. must be evidence to the effect that, in setting the price of one product, sellers carefully evaluate the price of another and how it is likely to change in response. This kind of evidence would be very interesting, but it is not very likely to exist, at least not in objective form. 
The factors listed by the Guidelines for assessing geographic substitution are very similar to those used in assessing product substitution. However, geographic issues tend to be far inore objective and tractable. The first factor, "evidence of buyers actually having shifted their purchases among sellers at different locations," is roughly equivalent to the buyers' perceptions factor for evaluating product substitution and has similar limitations. ${ }^{136}$ Historical substitution may be a poor indicator of substitution under prevailing and future conditions. Much the same can be said of the second factor, price moveinents. However, in the geographic context, price moveinents are even more likely to be misleading than in the product context. The retail price of gasoline at any particular station may move closely with the prices at stations hundreds or even thousands of miles away, but no one would go hundreds or thousands of miles to buy gasoline at retail, and such distant stations are not in the same retail market. Prices at one point in the vertical supply chain in various regions generally will move together if the regions are in the same market at some point upstream, even if the regions are not in the saine market at the stage of production that is of interest.

The Guidelines' third factor for evaluating geographic substitution is transportation costs. The utility of such information was established above. ${ }^{137}$ But information about transportation costs is of little use without additional information such as the location of buyers and sellers and f.o.b. prices. The example above assumed that sellers outside a possible market would be willing and able to produce in unlimited quantities at the present price. In inost cases that is not a realistic assumption, and it is necessary to obtain information about the sellers' "supply curves," that is, how inuch they would supply at various prices.

The Guidelines' fifth factor, "excess capacity," relates to such information. Where it is well defined, excess capacity indicates the extent to which a firm would be willing and able to increase its output at

136. See supra note 135 and accompanying text. The phrasing of the first factor is somewhat different in product and geographic contexts. In the product context, the Guidelines refer to "buyers' perceptions," whereas in the geographic context they refer only to actual substitution by buyers. The difference probably was not meant to convey any important distimction. Evidence of buyers' perceptions can be equally useful in both the product and geographic contexts whenever transportation costs are not the controlling factor in determining the extent of geographic substitution. Such was the situation in the first case the government litigated under the Guidelines. See 'Umited States v. Virginia Nat'1 Bankshares, Inc., 1982-2 Trade Cas. (CCH) 64,871 (W.D. Va. 1982). The major issue in the case was the gcographic dimensions of markets for banking service, and to illuminate this issue the government relied on evidence of buyers' perceptions expressed through a survey. For an overly critical view of the value of this evidence, see Wertheimer, $D O J$ Tries Out its S-Percent Geographic Market Test, LeGAl Times, Aug. 30, 1982, at 17.

137. See supra notes 122-30 and accompanying text. 
prices similar to those prevailing. ${ }^{138}$ The procedures for analyzing geographic substitution described in the example above can be usefully applied in many cases and can be refined very much furtler. The Department has undertaken a highly sophisticated application of this procedure in delineating the geographic dimensions of coal markets. ${ }^{139}$ Still, such procedures are not without significant limitations. If the merging firms produce highly differentiated consumer goods, such analysis is unlikely to be particularly useful because differences in consumer tastes, which cannot be modeled well, will be very important.

The Guidelines' final factor for evaluating geographic substitution is the cost of local distribution. The cost of establishing the necessary distribution network could prevent firms not already selling in an area from beginning to sell there if prices in the area rose. If the costs of local distribution were significant, a monopolist over a particular product in a particular area might impose a significant price increase even though transportation costs were not high enough to prevent outside sellers from shipping into the area. Thus, the analysis of geographic substitution described above has yet another limitation; it may not be reliable if distribution involves inuch nore than simply transporting the product. Identifying such cases may not be difficult, but determining the precise significance of local distribution costs will be. There is no rehable way to determine how high local distribution costs must be to dissuade firms froin establishing the distribution facilities necessaryi to begin selling, and, indeed, there is no simple way to ineasure such costs. At best, this can be used as a qualitative factor based on subjective evidence. Fortunately, there are likely to be few cases in which local distribution costs are important in delineating market boundaries.

In sum, geographic nnarket boundaries often can be established using fairly sophisticated and rehiable tools based on the locations of buyers and sellers and on transportation costs. However, many cases present difficult complications, and in some cases the suggested procedures may not be useful. Moreover, in most cases it will not be possible

138. The utility of "excess capacity" in market delineation depends on the precise meaning of the term in the industry in question. In many manufacturing industries, particularly process industries such as the chemical industry, capacity and excess capacity are well defined terms and are useful measures of the extent to which a firm could increase output at prices comparable to prevailing prices. On the other hand, some firms may be able to double their output but would do so only if price doubles. Such firms could be considered to have fifty percent excess capacity, but in such cases, excess capacity indicates little about the extent to which the firms could increase output at prices comparable to prevailing prices, and the information is of little value, in and of itself, in market delineation. For a particularly skeptical view of the relevance of excess capacity in a somewhat different context, see Schmalensee, supra note 14, at 1801-03, 1812-14.

139. See U.S. Dep't Of Justice, COMpetition IN THE COAL INDUSTRY ch. 3 (Dec. 1982). 
to use procedures comparable to those used in the geographic analysis to establish the product dimensions of markets, and reliable, objective evidence of markets' product dimensions generally will not be available. The Guidelines provide no specific rules or tests for determining either the product or geographic dimensions of markets, but their conceptual framework can be of great value. Market delineation should be considered on a case-by-case basis, using the best available information, analyzed by applying the Guidelines' market delineation primciples. In virtually all cases, these principles can be used in conjunction with readily available evidence to narrow greatly the range of plausible market boundaries. Combined with the Guidelines' market share standards, ${ }^{140}$ this should be sufficient to identify quickly most mergers that would be unlikely to create or enhance market power, which is by far the largest category of mergers. In the cases that remain, the Guidelines provide a useful framework for identifying probative evidence and evaluating its implications. Ultimate conclusions may have to be based on impressions and intuition, but one's intuition should be much keener with the Guidelines' framework than without it. If the Guidelines convey any important message about delineating markets in actual cases, it is that there are no hard-and-fast rules; it is the principle that is important.

\section{Contrasts Between the Guidelines' Approach to Market Delineation and Notable Alternatives}

The foregoing discussion describes the market delineation principles of the Guidelines. It also is useful to indicate what they are not; contrasts between the Guidelines' approach to market delineation and notable alternatives help to clarify the Guidelines' procedure.

\section{A. The 1968 Merger Guidelines.}

The original Merger Guidelines, issued in 1968, defined a market as

any grouping of sales (or other commercial transactions) in which each of the firms whose sales are included enjoys some advantage in competing with those firms whose sales are not included. The advantage need not be great, for so long as it is significant it defines an area of effective competition among the included sellers in which the coinpetition of the excluded sellers is, ex hypothesi, less effective. ${ }^{141}$

They also elaborated on the product and geographic dimensions of markets by stating:

140. 2 TRADE REg. ReP. (CCH) I 4503.10 .

141. Id. \4510 (emphasis added). 
The sales of any product or service which is distinguishable as a matter of commercial practice from other products or services will ordimarily constitute a relevant product market, even though, from the standpoint of most purchasers, other products may be reasonably, but not perfectly, interchangeable with it in terms of price, quality, and use. On the other hand, the sales of two distinct products to a particular group of purchasers can also appropriately be grouped into a single inarket where the two products are reasonably interchangeable for that group in terms of price, quality, and use.

The total sales of a product or service in any commercially significant section of the country (even as small as a single community), or aggregate of such sections, will ordinarily constitute a geographic market if firms engaged in selling the product nuake significant sales of the product to purchasers in the section or sections. The market need not be enlarged beyond any section ineeting the foregoing test unless it clearly appears that there is no economic barrier (e.g., significant transportation costs, lack of distribution facilities, custoiner inconvenience, or estabished consumer preference for existing products) that hinders the sale from outside the section to purchasers within the section; nor need the market be contracted to exclude some portion of the product sales made inside any section ineeting the foregoing test unless it clearly appears that the portion of sales in question is inade to a group of purchasers separated by a substantial economic barrier from the purchasers to whom the rest of the sales are made. ${ }^{142}$

Under the 1968 Guidelines, any product and area readily distinguishable from substitutes could be deemed a relevant market. This allowed the relevant market in any particular case to be essentially as small or as large as one wanted. For two merging firms producing a very similar product, the 1968 Guidelines sanctioned the delineation of markets with extremely narrow product dimensions and geographic dimensions of virtually any area in which the two firms both sold their products. On the other hand, if two merging firms produced different products or sold in different areas, a much larger market could be delineated to include both of them.

The new Guidelines establish principles that are very different in several respects. First, under the new Guidelines, it is not sufficient that there is some distinction between products or a barrier between areas; the distinction or barrier must be great enough to induce a present and future monopolist over a group of products in an area to increase price significantly. "As a first approximation," 143 the threshold for significance is a price increase of five percent for one year. Under

142. Id (emphasis added).

143. Id 8 4502.10, 4502.30 . 
the 1968 Guidelines, a product and area could be considered a market if a monopolist would mcrease price by any perceptible amount, even if it were much less than one percent. As explained above, it is very important to use a higher threshold than this. ${ }^{144}$ Second, the 1968 Guidelines seem to have presumed that price discrimination, at least geographic price discrimination, is always possible. This would explain why the 1968 Guidelines considered the geographic dimensions of the relevant market to be any section of the country in which the merging firms made significant sales. The new Guidelines do not maintain a similar presumption, but rather delineate narrower markets only if price discrimination is possible. ${ }^{145}$ Third, the 1968 Guidelines delineated broad 1narkets if the merging firms' products were imperfect substitutes but narrow markets if they were perfect substitutes. It seems implausible that broad and narrow markets are equally good bases for assessing the likelihood of collusion. Thus, one or the other approach probably should be taken regardless of the degree of substitutability between the products of the merging firms. The new Guidelines' general principle of clioosing the smallest market avoids the sort of market gerrymandering that the 1968 Guidelines permitted. 146 Finally, the new Guidelines have developed a mucl more complete and useful conceptual framework for thinking about market delineation issues.

\section{B. Cross-Elasticity of Demand.}

Possibly the only significant influence economists have had on judicial thinking about market delineation has been to introduce the concept of cross-elasticity of demand. ${ }^{147}$ The cross-elasticity of demand between two goods is the percentage change in the quantity of one that is produced by a certain percentage increase in the price of the other, divided by the percentage change in the price of the second good. ${ }^{148}$

144. See supra notes $72-76$ and accompanying text. The 1968 Guidelines were soundly criticized for their failure to require a higher significance threshold. See R. POSNER, supra note 14, at 131-32; Report of the TASK Force on Productivity and Competition [The Stigler RePORT] (1969), reprinted in $1 \mathrm{~J}$. REPRINTS FOR ANTITRUST L. \& ECON. 827, 847-48 (1969).

145. See supra notes $57-59$ and accompanying text. The Guidelines do not indicate the conditions under which one should conclude that price discrimination is possible. For a discussion of appropriate conditions, see supra note 58.

146. See supra notes $63-68$ and accompanying text.

147. Leading cases on market delineation that use the term are Brown Shoe Co. v. United States, 370 U.S. 294, 325 (1962); United States v. E.I. du Pont de Nemours \& Co., 351 U.S. 377, $394-404$ (1956).

148. Because either of two goods can be the first good in this definition, there are two crosselasticities of demand for any two goods. The two cross-elasticities geuerally are not equal. See Schmalensee, supra note 14, at 1815-16. Neither the merger cases nor the antitrust literature indicate which of these cross-elasticities one slould examine in delineating markets. 
Cross-elasticity of demand is an imdication of the degree of substitutability between two goods, and as such, it is a highly useful notion in considering market delineation issues. On the other hand, it is only the notion of cross-elasticity that is useful, not the measure itself. The Guidelines rightly reject the use of cross-elasticity of demand as the test of whether two products or areas are in the same market. ${ }^{149}$

The Guidelines consider an area and group of products to be a market if a profit-maximizing monopolist of that product in that area would significantly increase price. The extent to which a monopolist would increase price is largely a function of the own-elasticity of demand for the product and area-that is, the percentage change in the quantity demanded of the product in that area that is produced by a certaim percentage change in the price of that product in that area, divided by the percentage change in that price. ${ }^{150}$ Cross-elasticity is relevant only because it is closely related to own-elasticity. The ownelasticity of deinand for any product is determined largely by the crosselasticities of demand for that product with other products. ${ }^{151}$ Nevertheless, individual cross-elasticities provide a poor indication of the extent to which a monopolist would increase price.

A monopolist contenplating a price increase cares about the proportionate amount by which the quantity deinanded of its own product falls as price rises, which is indicated by the own-elasticity of demand. Cross-elasticities of demand indicate the proportionate amount by which the quantities demanded of other products change as the inonopolist's price rises, but that is unimportant to the inonopolist. Depending on the relative importance of the various products, given crosselasticities nay correspond to a wide range of own-elasticities. Similarly, cross-elasticities of demand indicate how the quantity demanded

149. The Guidelines' rejection of cross-elasticity of demand as a test is entirely implicit; the Guidelines never use the term.

150. Elasticities can be measured either for a specific, substantial change in price or for an arbitrarily small change in price. The former is an "arc elasticity" and the latter is a "point elasticity." The relevant elasticity measurement in delineating markets under the Guidelines is an arc elasticity measurement for a price increase of five percent above the prevailing price or some likely future price. This elasticity governs the profitability of the price increase postulated by the Guidelines in delineating markets.

151. The precise mathematical relationship is

$$
-\epsilon=1+\Sigma a_{i} \epsilon_{i}
$$

in which $\epsilon$ is the own-elasticity of demand for the good in question, $\epsilon_{\mathrm{i}}$ is the cross-elasticity of demand for good $i$ with respect to the price of the good in question, and $a_{i}$ is the proportion of income spent on good i divided by the proportion of income spent on the good in question. See, eg., J. Henderson \& R. Quandr, Microeconomic TheORY 33 (3d ed. 1980). Landes \& Posner, supra note 14, at $961 \mathrm{n} .43$, report a somewhat different expression in which the elasticities are those for a compensated demand function. Such a demand function is predicated on the assumption that consumers' incounes rise as prices rise so that their real incomes remain constant. 
of the monopolist's product changes when the prices of other products change, but this knowledge also is irrelevant to the monopolist's decision. Furthermore, the magnitudes of the cross-elasticities between a product and each of its substitutes may not be nearly as important as the number of substitutes a product has. Many very small cross-elasticities may do more than one large cross-elasticity to keep a monopolist from increasing price.

Finally, under the Guidelines demand conditions alone do not determine market boundaries. Both revenues and costs determine profit, but elasticity of demand relates only to revenues. In assessing the extent to which a monopolist would increase price, it is necessary to consider not only the extent to which a price increase would cause a reduction in quantity sold, but also the extent to which a reduction in quantity would reduce costs. - Demand conditions generally are the most important factors in determining the extent to which a monopolist would imcrease price, but cost conditions cannot be ignored.

\section{The "Submarkets" and "Practical Indicia" of Brown Shoe.}

In Brown Shoe Co. v. United States, ${ }^{152}$ the Supreme Court established a two-tiered approach to inarket delineation under section 7. First, the Court indicated that the "outer boundaries" of a "market are determined by reasonable interchangeability . . . or the cross-elasticity of demand."153 The Court then added:

[W]ithin this broad market, well-defined submarkets may exist which, in themselves, constitute product markets for antitrust purposes. The boundaries of such a submarket may be determined by examining such practical indicia as industry or public recognition of the submarket as a separate economic entity, the product's peculiar characteristics and uses, unique production facilities, distinct customers, distinct prices, sensitivity to price clranges, and specialized vendors. ${ }^{154}$

The extent to which the Guidelines' approach corresponds with cross-elasticity of demand, ${ }^{155}$ the first tier of analysis under Brown Shoe, was just discussed. The extent to which the Guidelines' approach corresponds with the second tier is somewhat unclear because the "submarket" concept of Brown Shoe is not well defined. Brown Shoe has been construed as endorsing the use of share calculations

152. 370 U.S. 294 (1962).

153. Id at 325.

154. Id. (citation and footnote omitted). The quoted material is from a discussion of the product dimensions of markets, but the general approach must have been intended to apply to their geographic dimensions as well.

155. See supra notes $147-51$ and accompanying text. 
based on "submarkets" that would not also be markets. ${ }^{156}$ The Guidelines do not permit such a procedure. To be deemed a market under the Guidelines, an area and group of products must be such that a hypothetical monopolist of those products in that area would increase price significantly. An area and a group of products that do not ineet this definition are of no special significance under the Guidelines. Moreover, share calculations for an area and group of products that do constitute a market are of no relevance under the Guidelines. On the other hand, the Guidelines recognize that there inay be markets within markets; the Guidelines' definition of a market generally implies an infinite number of concentric inarkets. Subject to important qualifications, however, the Guidelines consider only the smallest of these markets to be relevant. If price discrimination is possible, there may be additional, narrower relevant markets under the Guidelines. In no case, however, are any relevant inarkets called "subınarkets"; nor are they delineated according to the "practical indicia" of Brown Shoe.

The "practical indicia" probably were intended to be relatively simple, objective criteria to be used in the place of a detailed case-bycase analysis. Unfortunately, these simple, objective criteria are not very rehable. The "practical indicia" nay be relevant in many cases, but applying them mechanically is not likely to produce meaningful market boundaries in inost cases. The Guidelines' approach to 1narket delineation is fairly straightforward in abstract terms but cannot be reduced to simple "practical indicia." The Guidelines reflect a preference for a theoretically correct approach, logically derived from the ultimate goal of merger enforcement, over the simplicity of Brown Shoe.

\section{Shipments Tests for Geographic Dimensions of Markets.}

Brown Shoe's "practical indicia" are primarily intended to be used to delineate the product dimensions of inarkets. Conceptually similar criteria have also been proposed using data on product shipments to determine the geographic dimensions of markets. Most notable are those suggested by Kenneth Elzinga and Thoinas Hogarty: that a product and area be considered a market only if (1) relatively little of the product that is consumed in the area is produced outside it, and (2) relatively little of the product that is produced in the area is consumed outside it. ${ }^{157}$ For the sane reason that they reject the "practical indi-

156. See, e.g., R. POSNER, supra note 14, at 129.

157. See Elzinga \& Hogany, supra note 6, at 52-60; see also Elzinga \& Hogarty, The Problem of Geographic Market Definition Revisited: The Case of Coal, 23 ANTITRUST BULI. 1 (1978). An :ternative approach was suggested in Shrieves, Geographic Market Areas and Market Siructure in 
cia," the Guidelines reject the use of these simple, objective criteria for delineating the geographic dimensions of markets; such rules do not necessarily produce the right answer.

It is clear that a product and area need not be a market under the Guidelines even though there are neither imports of the product into the area nor exports of the product from the area. One need only consider the example in the previous section. ${ }^{158}$ Any circle, no matter how small, satisfies the Elzinga-Hogarty criteria, yet only circles of at least 155.6 miles are markets under the Guidelines. In sinaller areas, a significant price increase would not be imposed by a monopolist because the loss in sales would be too great. ${ }^{159}$ It is possible also for there to be significant exports of a product from an area even though that product and area are a market under the Guidelines. This can happen either because it is possible to price discriminate between local and distant customers or because, although discrimination is not possible, production costs are significantly lower in the area than elsewhere. In the latter case, competitive pricing would result in the area exporting to higher-cost areas, while a monopolist might be willing to forego those exports to increase price to local customers. ${ }^{160}$

There can be significant imports of a product into an area despite the fact that the product and area constitute a market under the Guidelines. Figure 2 above illustrates one such situation. ${ }^{161}$ If the seven sellers in the center of Figure 2 imcreased price until the area in which one of them was the low-delivered-price seller shrank to the inner figure (indicated by the light, solid line), the smallest circle containing the seven sellers would also contain a substantial number of customers who would buy from outside sellers. ${ }^{162}$ Giving their criteria the benefit of all doubt, one could presume that in such cases Elzinga and Hogarty

the Bituminous Coal Industry, 23 ANTTrRUST BULL 589 (1978). For an analysis of this approach, see Werden, The Use and Misuse of Shipments Data in Defining Geographic Markets, 26 ANr1TRUST BULL. 719 (1981).

158. See supra notes 122-30 and accompanying text.

159. Professor Elzinga recognizes this possibility. See Elzinga, Defining Geographic Market Boundaries, 26 ANTITRUST BULL. 739, 742-43 (1981).

160. For a geometric example of the latter situation, see Werden, supra note 157, at 727-29. See also id. at 730. For Professor Elzinga's reaction to this example, see Elzinga, supra note 159, at $746-48$.

161. See supra text accompanying note 129.

162. Such a possibility is not unreasonable. Under demand and cost conditions similar to those postulated in the example, the most profitable price increase for a monopolist would be that on which the figure is based. Of course, the Guidelines generally would not consider a product and area to be a market if price had already been increased to this point because a monopolist would not increase price above prevailing or likely future levels. See supra notes $43-45$ and accompanying text. However, the same qualitative result could easily be achieved in a situation in which the prevailing price was significantly below the monopoly price. 
would determine the geographic boundaries of the market to be the inner figure. ${ }^{163}$ In that event, however, there still may be significant imports of a product into an area, even though the product and area are considered a market under the Guidelines. This can happen if the product is highly differentiated and some of the consumers in the area have a strong preference for the products of outside sellers. ${ }^{164}$ The Guidelines adopt a case-by-case assessment of the available evidence to avoid such mistakes. ${ }^{165}$

\section{SUMMARY AND CONCLUSIONS}

This article has explored the logical underpinnings, theoretical details, and practical application of the Guidelines' market delineation principles. The Guidelines' approach to market delineation is derived directly from their "unifying theme"-mergers should not be permitted to create or enhance "market power."166 Exercises of market power generally consist of increases im price through the collective action of several firms; therefore, the Guidelines are primarily concerned with the likelihood of collusion. The likelihood of collusion, in turn, is indicated primarily by the size distribution of competitors. Thus, market delineation in the Guidelines is a tool used to construct market shares that are as meaningful as possible. The Guidelines consider an area and group of products to be a market if, and only if, a hypothetical unregulated, profit-maximizing firm that was the only present and future seller of those products in that area would impose a significant and non-transitory increase in price above prevailing or likely future levels. If this condition is not satisfied, the merger of any two competitors a fortiori could not create or enhance market power by facilitating collusion. To make market shares as meaningful as possible, the Guidelines separate the delineation of markets from the identification of competitors in them and from consideration of ease of entry into them. By phrasing the definition of a market in terms of what a present and future monopolist would do, the Guidelines initially restrict their focus to whether substitution by buyers would make a significant price increase

163. It must be emphasized that available data rarely will be sufficiently refined to afford such an opportunity. One often will be forced to work with data that specify only the state of origin and destination for shipments. Because the Elzinga-Hogarty test oflen must use only aggregated data, there often will appear to be significant imports of a product into an area, even though the product and area are a market.

164. See Kaplow, supre note 14, at 1836-38.

165. Shipments dats have other practical limitations. For a discussion of those limitations in the context of the coal industry, see U.S. DEP'T OF JUSTICE, supre note 139, at 23-24; Werden, supra note 157, at 726.

:66. 2 TRADE REG. ReP. (CCH) \ 4501. 
unprofitable. Only later in the analysis do the Guidelines take into account the extent to which collusion among present sellers would be deterred by the ability of those not currently selling the relevant product in the relevant area to begin doing so, through use of existing facilities or through de novo entry.

The Guidelines also adopt several principles to prevent gerrymandering of inarket sizes and shapes in ways that would make market shares less meaningful indicators of the likelihood of collusion. First, the Guidelines require that markets be circular in some sense, with the product and plant of one of the merging firms at the center. While the sense in which markets must be circnlar often is very abstract and may not be well defined, the Guidelines inaintain the basic principle of including in a market any product and location that are at least as good substitutes for the product and location of the inerging firm as any product and location that is included. Second, subject to important exceptions, the Guidelines choose as the relevant market the smallest area and group of products that clearly constitute a market. This eliminates the use of very broad unarkets in some cases and very narrow markets in others, depending on the market shares that would result. The Guidelines initially assume that price discrimination is not possible and delineate markets accordingly. If price discrimination is possible, the Guidelines delineate additional, narrower markets oriented to the consumer groups that could be the targets of discrimination. By making this process explicit, the Guidelines considerably slrarpen the issues of both market delineation and share measurement.

Application of the Guidelines' market delineation procedure is complicated by a number of unanswered questions. Their definition of a market refers to the monopolist's ability to mcrease "price," but "price" could be any of several different quantities. Furthermore, whether the monopolist's price increase would be deemed significant may depend on which price is used for comparison. Also critical is the amount and duration by which price inust increase before the increase is considered significant. The Guidelines do not indicate the appropriate base price, and it seems clear that there is no right answer. This issue probably is best left for case-by-case consideration. The Guidelines do propose specific significance thresholds. As a "first approximation" the Guidelines suggest that price must increase at least five percent for at least one year before the price increase will be considered significant. Although there is no clear basis for choosing any particular price and time thresholds, the Guidelines' first approximation seems fairly reasonable. On the other hand, there are several reasons why somewhat higher thresholds might be better. 
The Guidelines provide little direction concerning practical application of their procedure, and what direction they do provide is of little assistance. The Guidelines reject the simple, objective rules that have been suggested by others and propose none of their own; they establish a set of principles for delineating markets that calmot be reduced to simple, objective rules. In some cases it will be possible to make reliable, qualitative estimates of the extent to which a monopolist would mcrease price, but generally it will not. In most cases, the Guidelines provide only a conceptual framework for thinking about the issues; this is, however, not a small contribution. Indeed, the introduction of this conceptual framework is the Guidelines' major achievement.

It is too soon to know whether the market delineation principles embodied in the Guidelines will have a significant impact on litigation under section 7. It will take some time for them to be fully understood and even longer for courts to pass judgment on them. Present legal precedents on market delineation lack a coherent conceptual framework and provide trial judges little guidance in assessing the difficult questions of fact posed in inarket delineation. Judges should find life much easier and probably will produce significantly better decisions if they adopt the conceptual framework of the Guidelines. Rather than determining which opposing expert has the inore sensible approach, judges could more easily evaluate the critical factual issues if all the experts were forced to discuss the problem under a common set of principles such as those in the Guidelines. With luck the courts will also see it this way. 